\title{
New particle formation at urban and high-altitude remote sites in the south-eastern Iberian Peninsula
}

\author{
Juan Andrés Casquero-Vera ${ }^{1,2}$, Hassan Lyamani ${ }^{1,2}$, Lubna Dada $^{3}$, Simo Hakala ${ }^{3}$, Pauli Paasonen ${ }^{3}$, Roberto Román ${ }^{4}$, \\ Roberto Fraile $^{5}$, Tuukka Petäjä ${ }^{3}$, Francisco José Olmo-Reyes ${ }^{1,2}$, and Lucas Alados-Arboledas ${ }^{1,2}$ \\ ${ }^{1}$ Andalusian Institute for Earth System Research (IISTA-CEAMA), University of Granada, \\ Autonomous Government of Andalusia, Granada, Spain \\ ${ }^{2}$ Department of Applied Physics, University of Granada, Granada, Spain \\ ${ }^{3}$ Institute for Atmospheric and Earth System Research (INAR)/Physics, Faculty of Science, \\ University of Helsinki, Helsinki, Finland \\ ${ }^{4}$ Grupo de Óptica Atmosférica (GOA), Universidad de Valladolid, Valladolid, Spain \\ ${ }^{5}$ Department of Physics, University of Leon, Leon, Spain
}

Correspondence: Juan Andrés Casquero Vera (casquero@ugr.es)

Received: 23 April 2020 - Discussion started: 3 June 2020

Revised: 22 September 2020 - Accepted: 9 October 2020 - Published: 24 November 2020

\begin{abstract}
A substantial fraction of the atmospheric aerosols originates from secondary new particle formation (NPF), where atmospheric vapours are transformed into particles that subsequently grow to larger sizes, affecting human health and the climate. In this study, we investigate aerosol size distributions at two stations located close to each other $(\sim 20 \mathrm{~km}$ ) but at different altitudes: urban (UGR; $680 \mathrm{~m}$ a.s.l., metres above sea level) and high-altitude remote (SNS; 2500 m a.s.l.) sites, both in the area of Granada, Spain, and part of AGORA observatory (Andalusian Global ObseRvatory of the Atmosphere). The analysis shows a significant contribution of nucleation mode aerosol particles to the total aerosol number concentration at both sites, with a contribution of $47 \%$ and $48 \%$ at SNS and UGR, respectively. Due to the important contribution of NPF events to the total aerosol number concentrations and their high occurrence frequency $(>70 \%$ ) during the study period, a detailed analysis of NPF events is done in order to get insight into the possible mechanisms and processes involved in NPF events at these contrastive sites. At SNS, NPF is found to be associated with the transport of gaseous precursors from lower altitudes by orographic buoyant upward flows. NPF events at the SNS site are always observed from the smallest measured sizes of the aerosol size distribution $(4 \mathrm{~nm})$, implying that NPF takes place in or in the vicinity of the high-altitude SNS station rather than being transported from lower alti-
\end{abstract}

tudes. Although NPF events at the mountain site seem to be connected with those occurring at the urban site, growth rates (GRs) at SNS are higher than those at the UGR site $\left(\mathrm{GR}_{7-25}\right.$ of 6.9 and $4.5 \mathrm{~nm} \mathrm{~h}^{-1}$ and $\mathrm{GR}_{4-7}$ of 4.1 and $3.6 \mathrm{~nm} \mathrm{~h}^{-1}$ at SNS and UGR, respectively). This fact could have special importance for the production of cloud condensation nuclei $(\mathrm{CCN})$ and therefore for cloud formations which may affect regional/global climate, since larger GRs at mountain sites could translate to a larger survival probability of NPF particles reaching $\mathrm{CCN}$ sizes, due to the shorter time period needed for the growth. The analysis of sulfuric acid $\left(\mathrm{H}_{2} \mathrm{SO}_{4}\right)$ shows that the contribution of $\mathrm{H}_{2} \mathrm{SO}_{4}$ is able to explain a minimal fraction contribution to the observed GRs at both sites $(<1 \%$ and $<10 \%$ for the $7-25$ and $4-7 \mathrm{~nm}$ size ranges, respectively), indicating that other condensing vapours are responsible for the majority of particle growth, as well as the differing growth rates between the two sites. Results also show that the condensation sink (CS) does not play a relevant role in NPF processes at both sites and points to the availability of volatile organic compounds (VOCs) as one of the main factors controlling the NPF events at both sites. Finally, a closer analysis of the NPF events that were observed at the SNS site during a Saharan dust episode that occurred during the field campaign was carried out, evidencing the role of $\mathrm{TiO}_{2}$ and $\mathrm{F}_{2} \mathrm{O}_{3}$ together with VOCs in promoting new particle formation during this dust intrusion event. Although 
further investigation is needed to improve our understanding in this topic, this result suggests that climate effects of mineral dust and NPF are not disconnected from each other as it was commonly thought. Therefore, since mineral dust contributes to a major fraction of the global aerosol mass load, dust-NPF interaction should be taken into account in global aerosol-climate modelling for better climate change prediction.

\section{Introduction}

The formation of new atmospheric aerosol particles, and their subsequent growth, commonly known as new particle formation (NPF) events, has a substantial contribution to aerosol particle number concentration and thus affects the climate via aerosol-cloud interactions (Kerminen et al., 2018). Kulmala et al. (2014) described NPF events as a five-step process: (1) chemical reactions in the gas phase producing lowvolatility vapour(s), (2) clustering, (3) nucleation or barrierless nucleation, (4) activation of clusters with a second group of vapours, and (5) subsequent multi-component condensational growth of nucleated particles to larger sizes. However, despite the advancement in theoretical knowledge of NPF steps, large discrepancies have been found between the expected and observed properties of NPF under atmospheric conditions (Chu et al., 2019; Kulmala et al., 2017; Nieminen et al., 2018). Thus, more NPF studies in different environments and conditions are still needed for better understanding of the NPF processes.

Sulfuric acid $\left(\mathrm{H}_{2} \mathrm{SO}_{4}\right)$ has been commonly considered as one of the main precursors for aerosol nucleation and growth due to its low vapour pressure. However, $\mathrm{H}_{2} \mathrm{SO}_{4}$ alone is not sufficient to explain the observed NPF under various ambient conditions (Kulmala et al., 2004; Kulmala and Kerminen, 2008; Zhang et al., 2012). Earlier studies indicated that ammonia $\left(\mathrm{NH}_{3}\right)$ enhances aerosol nucleation, but recent laboratory and theoretical studies suggest that amines and highly oxygenated molecules (HOMs) play vital roles in enhancing nucleation and promoting the initial growth of newly formed particles in the atmosphere (e.g., Kulmala et al., 2013; Schobesberger et al., 2013; Tröstl et al., 2016; Ehn et al., 2014).

New particle formation accounts for approximately $50 \%$ of the aerosol number concentration production in the troposphere (Merikanto et al., 2009; Spracklen et al., 2010), but frequency, intensity or duration of NPF events are highly variable, with the prediction of NPF events being a current challenge of large interest. It is known that various factors favour the occurrence of NPF events. Precursor gases, concentration of pre-existing aerosol, meteorological variables and solar radiation are some of these key factors that govern NPF events (Dada et al., 2017). However, current knowledge about NPF processes remains poor, especially at high alti- tudes, i.e. above $1000 \mathrm{~m}$ (Rose et al., 2015), and at megacities (Kulmala et al., 2017; Yao et al., 2018), and a more profound understanding of the mechanisms and precursor gases involved in nucleation and particle growth is currently required, especially to improve the accuracy of climate models. Thus, in order to improve the actual understanding of NPF events, it is necessary to characterize NPF events at different environments with a distinct mixture of anthropogenic and natural precursor gas emissions and meteorological conditions.

Aerosol also plays an important role in the process of cloud formation by acting as cloud condensation nuclei (CCN) (e.g., Pierce and Adams, 2009; Spracklen et al., 2008). The aerosol-cloud interaction depends, mainly, on the water vapour supersaturation and the chemical composition and size distribution of the aerosol particles. Typically, the size at which aerosols activate as $\mathrm{CCN}$ ranges from 50 to $150 \mathrm{~nm}$ (Kerminen et al., 2012). However, some observational studies have showed that particles do not have to grow to sizes above $50 \mathrm{~nm}$ to be able to act as $\mathrm{CCN}$, and particles as small as $20 \mathrm{~nm}$ can form cloud droplets (e.g., Fan et al., 2018; Leaitch et al., 2016; Leng et al., 2014). In this sense, NPF events are one of the main processes producing aerosols in these sizes that has been estimated to enhance CCN number concentration by a factor of 1.2-1.8, depending on supersaturation (e.g., Dameto de España et al., 2017; Leng et al., 2014).

Due to the role of NPF in the production of CCN, it is of special interest to characterize NPF in the free troposphere (FT) and its vertical distribution. However, only a few studies have focused on the vertical distribution of these events (e.g., Carnerero et al., 2018; Komppula et al., 2003), and the existing observations of NPF at high altitudes provide contradictory results. For example, Crumeyrolle et al. (2010) showed that the occurrence of NPF events was limited to the planetary boundary layer (PBL), while Hamburger et al. (2011) have reported the presence of high concentrations of ultrafine particles in the upper FT, and Boulon et al. (2011) found that the nucleation processes were more frequent in a highaltitude site than in the PBL, due to enhanced ion contribution to NPF at high altitudes. Also, the occurrence of the NPF in the FT has been reported to be tightly connected with the strength of boundary layer influence at the site, together with global radiation (Bianchi et al., 2016; Tröstl et al., 2016). Furthermore, Foucart et al. (2018) suggested that the turbulent mixing between the boundary layer and the FT could enhance the NPF events at the interface between these layers. Thus, NPF studies, especially at high altitudes where environmental conditions favour cloud formation, are still needed for improving our understanding of the NPF processes.

Long-term observations at high altitudes are difficult to perform due to the lack of availability of suitable sites and due to adverse meteorological conditions. Also, interpretation of data from high-altitude stations must be done with care, as a station may not always be representative of the al- 
titude it lies at due to frequent valley winds and topographic effects (Sellegri et al., 2019). In the last years, some studies of NPF were conducted in high-altitude sites (Boulon et al., 2011; García et al., 2014; Rose et al., 2015), but better understanding of the NPF processes in high-altitude sites is still needed. Event frequency, growth and formation rates of NPF events at high-altitude stations differ greatly from each other, and new insights in this field are necessary (Sellegri et al., 2019).

In this study, we investigate aerosol size distributions in the size range $4-500 \mathrm{~nm}$ measured simultaneously during an intensive summer campaign at two stations located close to each other $(\sim 20 \mathrm{~km})$ but at different altitudes: urban (680 ma.s.l., metres above sea level) and high-altitude remote (2500 m a.s.1.) sites, in southern Spain. We also analysed and discussed the occurrence frequency, characteristics and factors that promote/inhibit NPF processes at these contrastive sites during this campaign. The role of precursor gases such as sulfuric acid and volatile organic compounds and their contribution to the formation and growth of aerosol particles at these two different environments are explored. Finally, a closer analysis of the NPF events that were observed during a Saharan dust episode that occurred during the field campaign was carried out in order to get insight into the processes and constituent components that lead to the formation of new particles during this dust intrusion event.

\section{Measurements and methods}

\subsection{Measurement sites and instrumentation}

Measurements were conducted in the framework of the SLOPE II campaign (Sierra Nevada Lidar AerOsol Profiling Experiment II). The SLOPE II campaign was developed along summer 2017 (May-September) combining active and passive remote sensing with in situ measurements at two different altitude sites in the northern slope of the Sierra Nevada mountain range (Granada, Spain). The measurements used were obtained during an intensive campaign from 23 June to 24 July at the Granada urban station (UGR) and Sierra Nevada remote station (SNS), both sites included in the AGORA observatory (Andalusian Global ObseRvatory of the Atmosphere). During this intensive campaign, these two permanent stations were also equipped with extra equipment, monitoring a large variety of aerosol properties, gaseous species and radiation parameters.

The UGR urban station is located in the Andalusian Institute for Earth System Research (IISTA-CEAMA), in the city of Granada, Spain (37.16 $\mathrm{N}, 3.61^{\circ} \mathrm{W}, 680 \mathrm{~m}$ a.s.l.). Granada is a Spanish city located in the south-eastern Iberian Peninsula, in a natural basin surrounded by mountains, especially by the mountain range of the Sierra Nevada, with peaks up to $3300 \mathrm{~m}$ a.s.l., showing a Mediterranean-continental climate. It is a medium-size city with a population of about
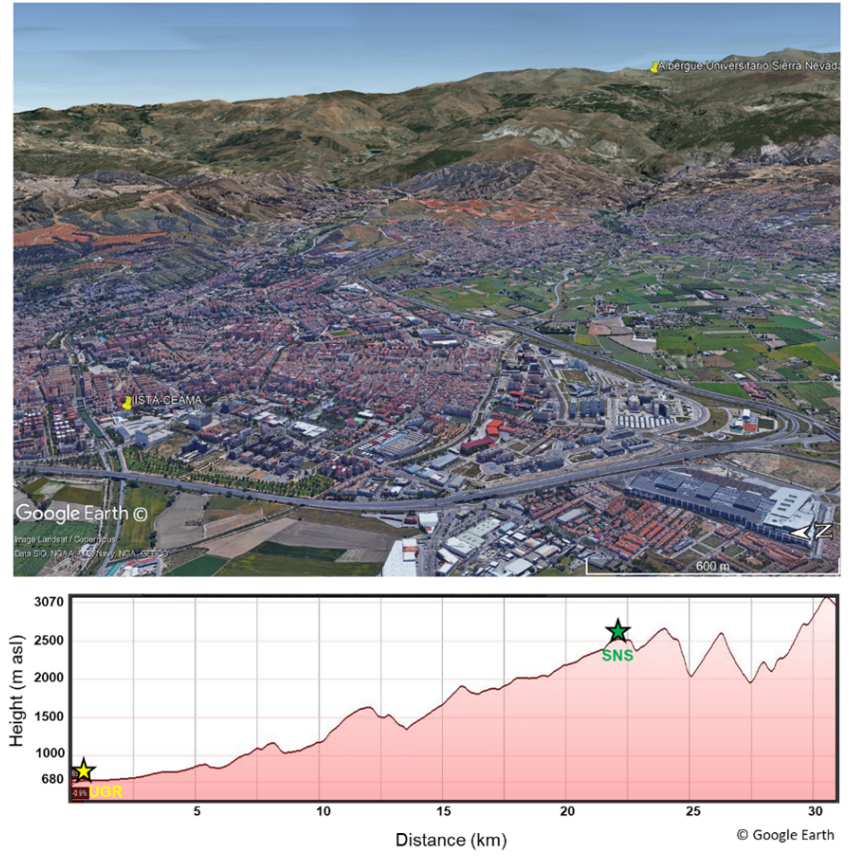

Figure 1. Map of Granada and Sierra Nevada and topographic profile between UGR and SNS stations. Yellow pins show the location of UGR and SNS stations.

250000 inhabitants. Granada is a non-industrialized city and one of the Spanish cities that suffers from pollution problems (Casquero-Vera et al., 2019). The main aerosol sources in the city of Granada are domestic heating based on fuel oil combustion and biomass burning in winter, Saharan desert dust in summer, and heavy traffic throughout the year (Lyamani et al., 2010, 2011; Patrón et al., 2017; Titos et al., 2012, 2017).

The SNS remote station $\left(37.10^{\circ} \mathrm{N}, 3.39^{\circ} \mathrm{W}, 2500 \mathrm{~m}\right.$ a.s.1.) is located in the northern slope of the Sierra Nevada mountain range, $\sim 5 \mathrm{~km}$ north-west of the Veleta summit (3398 $\mathrm{m}$ a.s.1.) and $\sim 20 \mathrm{~km}$ south-east of the city of Granada (Fig. 1). Due to its location with respect to the valley, prevalent wind directions are mainly from westerly and southerly directions, which favours the transport of pollutants from lower altitudes, mainly from the city of Granada, to SNS station. Thus, this station provides measurements, which can represent the south-western European free troposphere as well as give us insight on the impact of the aerosol particles transported from lower altitudes, especially from Granada, the nearest city, and its surroundings.

Both stations are equipped with a large number of instruments for measuring aerosol properties as well as radiation and meteorological parameters (wind speed and direction, temperature, relative humidity, pressure, and precipitation). Aerosol properties and meteorological as well as radiation parameters were measured with the same instrumentation model at both stations, following same calibration procedure and data quality criteria. Focusing on the measurements used in this work, aerosol particle number size distributions 
from 4 to $500 \mathrm{~nm}$ were measured every $5 \mathrm{~min}$ by nano-SMPS and SMPS (TSI model 3938), both composed of an electrostatic classifier (TSI 3082) and a condensation particle counter (CPC; TSI 3772 for SMPS and TSI 3775 for nanoSMPS) using aerosol flow rates of $1.0 \mathrm{~L} \mathrm{~min}^{-1}$ (SMPS) and $1.5 \mathrm{~L} \mathrm{~min}^{-1}$ (nano-SMPS) and sheath flow of $5.0 \mathrm{~L} \mathrm{~min}^{-1}$ for both systems. The quality of the SMPS measurements was checked for flow rates, relative humidity (RH), $203 \mathrm{~nm}$ polystyrene latex particles (PSL) calibration and in situ intercomparison (ACTRIS Round Robin Tour), following the ACTRIS and GAW recommendations (Wiedensohler et al., 2012, 2018). Following SMPS calibration procedures, uncertainty in the measured particle size distribution is within $10 \%$ and $20 \%$ for the size ranges $20-200$ and $200-800 \mathrm{~nm}$, respectively (Wiedensohler et al., 2018).

UV-B (280-320 nm) was monitored using UVB-1 (Yankee Environmental Systems) pyranometers, wind speed and direction were measured with R. M. Young 05102 anemometers, and temperature and humidity were measured with Rotronic HygroClip 2 (HC2) probes. Particle number size distribution in the aerodynamic diameter range of $0.5-20 \mu \mathrm{m}$ was measured with an aerodynamic particle sizer (APS; TSI model 3321). Aerosol $24 \mathrm{~h} \mathrm{PM}_{10}$ samples were collected on quartz fibre filters by means of a high-volume sampler with a flow rate of $30 \mathrm{~m}^{3} \mathrm{~h}^{-1}$. The filters were conditioned and treated pre- and post-sampling, and major elements (Al, $\mathrm{Ca}, \mathrm{K}, \mathrm{Mg}, \mathrm{Fe}, \mathrm{Ti}, \mathrm{Mn}, \mathrm{P}, \mathrm{Na}$ ) were determined by inductively coupled plasma mass spectrometry (ICP-MS) at the Institute of Environmental Assessment and Water Research (IDAEA-CSIC, Barcelona, Spain) following the procedure of Querol et al. (2001). Detection limit and accuracy were estimated in $0.02 \mathrm{ng} \mathrm{m}^{-3}$ and $3 \%$ (Pandolfi et al., 2011). The concentrations of $\mathrm{TiO}_{2}$ and $\mathrm{Fe}_{2} \mathrm{O}_{3}$ were indirectly determined on the basis of empirical factors $\left(\mathrm{TiO}_{2}=\mathrm{Ti} \cdot 0.6\right.$ and $\mathrm{Fe}_{2} \mathrm{O}_{3}=\mathrm{Fe} \cdot 0.7$ ).

Pollutant gas (CO, NO, $\mathrm{NO}_{2}, \mathrm{NO}_{x}, \mathrm{SO}_{2}$ and $\left.\mathrm{O}_{3}\right)$ data from the Ciudad Deportiva air quality station were used. This station is an urban background station located $\sim 3 \mathrm{~km}$ from the UGR station. These data are provided by the Junta de Andalucía (http://www.juntadeandalucia.es/medioambiente, last access: 15 November 2020), following the requirements of the European AQ directives. At the SNS station, concentrations of trace gases $\left(\mathrm{CO}, \mathrm{NO}, \mathrm{NO}_{2}, \mathrm{NO}_{x}, \mathrm{SO}_{2}\right.$ and $\mathrm{O}_{3}$ ) were monitored, following the European $\mathrm{AQ}$ directive requirements, by a mobile cabin of the University of Évora. Finally, ambient air samples were collected at both sites on TENAX, C18 and DNPH cartridges with a maximum $12 \mathrm{~h}$ time resolution by low-volume pumps. Volatile organic compounds retained on solid-phase filters are then chemically analysed using gas chromatography or liquid chromatography coupled to mass spectroscopy techniques (Borrás, 2013).

\subsection{Data analysis}

In order to gain some insight upon the sources and processes contributing to particle number concentrations over both sites, we segregated the $5 \mathrm{~min}$ particle size distributions measured by SMPS into three diameter ranges: nucleation mode from 4 to $25 \mathrm{~nm}\left(N_{4-25}\right)$, Aitken mode from 25 to $100 \mathrm{~nm}\left(N_{25-100}\right)$ and accumulation mode from 100 to $500 \mathrm{~nm}\left(N_{100-500}\right)$. This is because these distinct particle modes result from different emission sources and chemical and physical processes (e.g., Hama et al., 2017, and references therein). In addition, total particle number concentration is calculated from the whole 4 to $500 \mathrm{~nm}$ range $\left(N_{\text {Tot }}\right)$.

The classification of NPF event days was done by visual inspection of the daily particle number size distribution data according to the guidelines presented by Dal Maso et al. (2005). According to this classification criteria, days are classified and separated into four groups: event (E), nonevent (NE), undefined (UN) and bad-data days (BD). (1) "E" days are days during which sub- $25 \mathrm{~nm}$ particle formation and their consequent growth are observed, (2) "NE" days are days on which neither new growing modes nor production of sub- $25 \mathrm{~nm}$ particles are observed, (3) "UN" days are the days which do not fit either of the previous classes, and (4) "BD" days are the days during which data are not valid or inexistent. In addition, event days are separated into two different groups: class I and II events. NPF events are classified as class I events when the NPF growth rate retrieval is possible from 7 to $25 \mathrm{~nm}$ and class II when it is not possible.

In this study, the automatic DO-FIT algorithm (Hussein et al., 2005) is used to describe the measured particle number size distributions by fitting multiple log-normal distributions to the measured data. The geometric mean diameters of the fitted distributions are then used for calculating particle growth rates during NPF events. This is done by calculating the slope of the linear fit to the geometric mean diameters as a function of time, which were identified to represent the growing particle mode formed in an NPF event. Thus, the growth rate (GR) is obtained as

$\mathrm{GR}_{\Delta D_{\mathrm{p}}}=\frac{\mathrm{d} D_{\mathrm{p}}}{\mathrm{d} t}=\frac{\Delta D_{\mathrm{p}}}{\Delta t}$

where $D_{\mathrm{p}}$ is the representative diameter of the NPF mode at time $t$. In this work, the growth rates in the range 4-7 $\left(\mathrm{GR}_{4-7}\right)$ and $7-25 \mathrm{~nm}\left(\mathrm{GR}_{7-25}\right)$ were calculated. The uncertainties in the calculated GRs were estimated on $19 \%$ and $8 \%$ for the 3-7 and 7-20 nm size ranges (Yli-Juuti et al., 2011).

The formation rate $\left(J_{D_{\mathrm{p}}}\right)$ is defined as the flux of particles past the lower limit of the size range $\left(\Delta D_{\mathrm{p}}\right)$, and it is obtained by adding up the observed change in the observed particle number concentration and the losses of particles due to coagulation and growth out of the size range $\left(\Delta D_{\mathrm{p}}\right)$, and it is calculated following the methodology described by Kul- 
mala et al. (2012):

$J_{D_{\mathrm{p}}}=\frac{\mathrm{d} N_{\Delta D_{\mathrm{p}}}}{\mathrm{d} t}+\operatorname{CoagS}_{\Delta D_{\mathrm{p}}} \cdot N_{\Delta D_{\mathrm{p}}}+\frac{\mathrm{GR}_{\Delta D_{\mathrm{p}}}}{\Delta D_{P}} \cdot N_{\Delta D_{\mathrm{p}}}$,

where the first term on the right-hand side represents the rate of change of particle concentration with time (where $N_{\Delta D_{\mathrm{p}}}$ is the particle number concentration in the size range $\Delta D_{\mathrm{p}}$ ), the second term describes the loss of particles due to coagulation with larger aerosol particles (where $\operatorname{CoagS}_{\Delta D_{\mathrm{p}}}$ is the coagulation sink), and the third term considers the growth out of the considered size range. The coagulation sink was calculated from the geometric mean of the considered size range $\left(\Delta D_{\mathrm{p}}\right)$ to the upper SMPS diameter limit $(500 \mathrm{~nm})$, according to Kulmala et al. (2001). In this study, we calculated the formation rates at diameters $\left(D_{\mathrm{p}}\right) 4 \mathrm{~nm}\left(J_{4}\right)$ and $7 \mathrm{~nm}\left(J_{7}\right)$ using the diameter range $\left(\Delta D_{\mathrm{p}}\right)$ of 4-7 and 7-25 nm, respectively.

The condensation sink (CS) describes how rapidly vapour molecules will condense onto pre-existing aerosols. CS is dependent on the effective surface area of the pre-existing particle size distribution (Kulmala et al., 2012). Accordingly, the $\mathrm{CS}$ is calculated from each size distribution as

$$
\mathrm{CS}=2 \pi D \int_{D_{\min }}^{D_{\max }} D_{\mathrm{p}} \beta_{M} N_{D_{\mathrm{p}}} d D_{\mathrm{p}}=2 \pi D \sum_{D_{\mathrm{p}}} D_{\mathrm{p}} \beta_{M} N_{D_{\mathrm{p}}},
$$

where $D$ is the diffusion coefficient of condensable vapour, which is assumed to be sulfuric acid, and $\beta_{M}$ is the transitional correction factor (Fuchs and Sutugin, 1971), which is dependent on the mean free path of vapour molecules and aerosol diameter (e.g., Kulmala et al., 2001; Pirjola et al., 1999).

In order to quantify the contribution of $\mathrm{H}_{2} \mathrm{SO}_{4}$ to new particle formation and growth, we determine the concentration of condensable vapour required for a growth rate of $1 \mathrm{~nm} \mathrm{~h}^{-1}$ $\left(C_{\mathrm{V}}\right)$ following the Nieminen et al. (2010) procedure. For better estimation of condensable vapour concentration, $C_{\mathrm{v}}$ was retrieved by using the mass and density of the sulfuric-acidwater mixture (Kurtén et al., 2007) taking into account the differences in temperature and RH between SNS and UGR station.

Since the concentration of $\mathrm{H}_{2} \mathrm{SO}_{4}$ was not measured at either station, a proxy of $\mathrm{H}_{2} \mathrm{SO}_{4}$ concentration is used in order to define whether $\mathrm{H}_{2} \mathrm{SO}_{4}$ is the precursor vapour responsible for NPF at both stations and if so to link the new particle formation rates with the $\mathrm{H}_{2} \mathrm{SO}_{4}$ concentrations The proxy calculation was first proposed by Petäjä et al. (2009), which derives $\mathrm{H}_{2} \mathrm{SO}_{4}$ concentration from its formation through $\mathrm{SO}_{2}$ concentration in the presence of global radiation, UV-B, or $\mathrm{OH}$ and its loss to $\mathrm{CS}$. To estimate the $\mathrm{H}_{2} \mathrm{SO}_{4}$ concentration for our two stations, we used the following formula (Petäjä et al., 2009):

$\mathrm{H}_{2} \mathrm{SO}_{4}=k \cdot \frac{\mathrm{SO}_{2} \cdot \mathrm{UVB}}{\mathrm{CS}}$, where $\mathrm{SO}_{2}$ is sulfur dioxide concentration, UV-B is the radiation with wavelength from 280 to $320 \mathrm{~nm}$ and $k$ is a scaling factor. For this work, we use the $k$ value reported by Petäjä et al. (2009) based on measurements in the Hyytiälä SMEAR II station $\left(k=8.4 \times 10^{-7} \cdot \mathrm{UVB}^{-0.68}, \mathrm{~m}^{2} \mathrm{~W}^{-1} \mathrm{~s}^{-1}\right)$. The choice of $k$ value will have an influence on the absolute value of the $\mathrm{H}_{2} \mathrm{SO}_{4}$ concentrations but not on the relative variability. Then, the particle growth rate by sulfuric acid is calculated directly as the ratio of $\mathrm{H}_{2} \mathrm{SO}_{4}$ and the concentration of condensable vapours required for a growth rate of $1 \mathrm{~nm} \mathrm{~h}^{-1}\left(C_{\mathrm{v}}\right)$.

Finally, the dimensionless survival probability parameter $(P)$ proposed by Kulmala et al. (2017) was calculated as

$P=\mathrm{CS}^{\prime} / \mathrm{GR}^{\prime}$,

where $\quad \mathrm{CS}^{\prime}=\mathrm{CS} /\left(10^{-4} \mathrm{~s}^{-1}\right) \quad$ and $\mathrm{GR}^{\prime}=\mathrm{GR}_{7-25} /\left(1 \mathrm{nmh}^{-1}\right)$. The $\mathrm{CS}$ and $\mathrm{GR}$ values used were calculated with the methods described previously. The larger the survival parameter is, the smaller percentage of newly formed particles will survive to greater sizes. Values of $P$ smaller than 50 are typically required for NPF occurrence in clean and moderately polluted environments, although higher values of $P$ (up to 200) are observed for NPF events in highly polluted atmospheres (Kulmala et al., 2017).

\section{Results and discussion}

\subsection{Atmospheric aerosol number concentrations}

During the intensive SLOPE II campaign, $32 \mathrm{~d}$ of coincident aerosol number concentration measurements at the SNS and UGR station were recorded. A statistical summary of daily mean particle number concentrations in different size ranges $\left(N_{4-25}, N_{25-100}, N_{100-500}\right.$ and $\left.N_{\text {Tot }}\right)$ at the SNS and UGR station is presented in Table 1. As expected, the average total particle number concentration during the whole campaign period at the UGR urban station was clearly twice as large (mean value of $8.4 \times 10^{3} \mathrm{~cm}^{-3}$ ) than at the remote SNS station $\left(3.4 \times 10^{3} \mathrm{~cm}^{-3}\right)$ due to a large contribution from local anthropogenic emissions in the urban environment. In general, the direct comparison of the results obtained in this study with those reported in literature is difficult, and large differences in the aerosol number concentrations between the different sites may result from differences in the measured size ranges, instrumentation, sampling period, site location and proximity to the sources. However, the average aerosol concentration measured at the UGR urban station was in the range of those obtained in the summer season $\left(4-24 \times 10^{3} \mathrm{~cm}^{-3}\right)$ in other European urban sites (e.g., Birmili et al., 2016; Gómez-Moreno et al., 2011; Pérez et al., 2010; Pey et al., 2010). On the other hand, the mean aerosol concentration at SNS was slightly higher than that observed at Puy de Dôme (research station located at $1465 \mathrm{~m}$ a.s.l. in central France), where $N_{10-1000}$ values were $2.5 \times 10^{3} \mathrm{~cm}^{-3}$ 
in summer (Venzac et al., 2009). However, the mean aerosol concentration at SNS was significantly higher than that reported (mean $N_{10-1000}$ of $767 \mathrm{~cm}^{-3}$ in July) for Jungfraujoch (high-alpine station located at $3580 \mathrm{~m}$ a.s.l. in the central Swiss Alps) by Weingartner et al. (1999). Aerosol number concentrations at remote sites are rather influenced by longrange transport or/and by transport from lower altitudes in the case of remote mountain sites. Therefore, aerosol transport from lower altitudes (i.e. from the city of Granada) could partly explain the high aerosol concentration observed over the SNS station.

Table 1 also shows that the ratios between aerosol number concentrations measured at SNS and UGR are similar for all size ranges $\left(N_{\mathrm{Tot}}-41 \%, N_{4-25}-43 \%, N_{25-100}-44 \%\right.$ and $\left.N_{100-500}-44 \%\right)$. Consequently, the contributions of each aerosol mode to the total aerosol number concentration are similar at both locations. For example, accumulation mode $\left(N_{100-500}\right)$ has a contribution of $11 \%$ at both sites, whereas Aitken mode $\left(N_{25}-100\right)$ contributed $40 \%$ to the total aerosol number concentrations at both measurement sites. Finally, nucleation mode $\left(N_{4-25}\right)$ is the main contributor to the total aerosol number concentration at both sites during the whole campaign, representing $49 \%$ of the total aerosol number concentration at both sites.

Although the contributions of the different modes to total particle number concentration are similar at both sites, Fig. 2 shows that diurnal patterns differ from one site to another, revealing that the aerosol concentrations at both sites are influenced by different sources and mechanisms. $N_{25-100}$ and $N_{100-500}$ diurnal patterns at the UGR station show two peaks (one in the morning and other in the evening) in coincidence with those observed in black carbon (BC; a good tracer of traffic emissions; Lyamani et al., 2011) diurnal pattern (Fig. S1 in the Supplement). These diurnal patterns are evidence for the large impact of anthropogenic emissions, mainly traffic emissions, on the aerosol concentrations at the UGR site. The similar pattern is observed for $N_{\text {Tot }}$ at this site, but with a third peak overlapping the morning traffic rush hour peak. This third peak is observed around 10:0012:00 UTC in coincidence with an increase in nucleation mode aerosol number concentration $\left(N_{4-25}\right)$. This peak is related to the occurrence of NPF events at UGR due to an increase in atmospheric photochemistry as can be seen later. On the other hand, the total aerosol concentration at SNS shows an evident diurnal cycle with a peak around 12:0016:00 UTC. This peak is probably associated with the evolution of the boundary layer that transports gases and aerosol from lower altitudes (Fig. S1) or with the occurrence of NPF events at the SNS site, since an increase in nucleation mode aerosol concentration is also observed.

Although on average the total particle number concentration at UGR is larger than at the SNS station, temporal evolution of $N_{\text {Tot }}$ shows that during some days the total aerosol concentration at SNS was higher than those observed at the UGR urban station. These high aerosol total

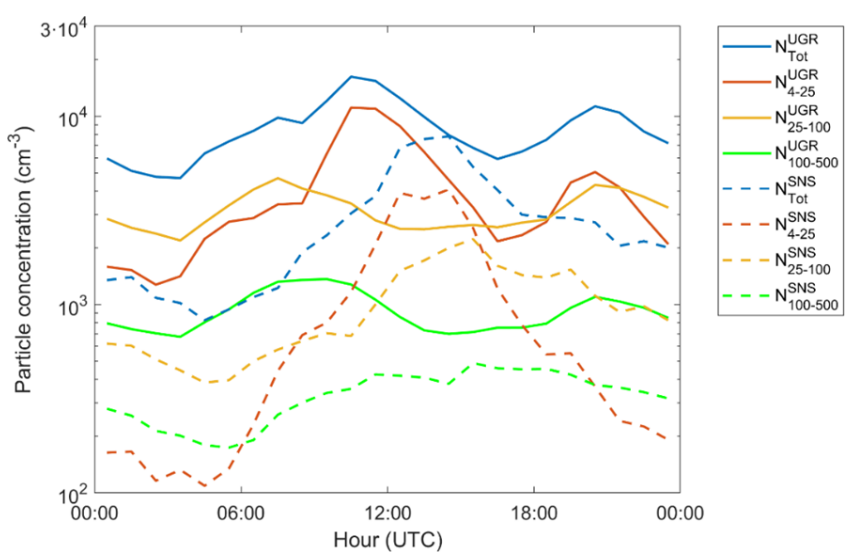

Figure 2. The mean diurnal variation of particle concentrations in different size ranges at SNS and UGR for the whole analysed period.

concentrations at SNS are also associated with high $N_{4-25}$ concentrations, both peaking around 12:00 UTC. The observed peaks in $N_{4-25}$ concentrations $\left(\sim 4 \times 10^{3} \mathrm{~cm}^{-3}\right)$ are more than 40 times larger than the background concentrations $\left(\sim 100 \mathrm{~cm}^{-3}\right)$ observed during night-time, suggesting that these cases are probably associated with strong NPF events occurring at the SNS site. Due to the observed high contribution of nucleation mode and the suggested relevance of NPF events at both sites, an in-depth study of NPF events is carried out in the next section.

\subsection{New particle formation analysis}

The results of NPF classification (events, non-events, or undefined and bad-data days) are summarized in Table 2. At both sites, a high NPF event frequency $(>70 \%)$ is observed, with 19 and 23 events at SNS and UGR, respectively. For many years, it was thought that NPF events cannot take place in urban areas, where the high pre-existing aerosol concentrations were considered detrimental in suppressing the formation and growth of particles due to a high condensation sink. However, our results show slightly higher frequency of NPF events at the UGR urban site in comparison to the remote site, which could be attributed to the higher availability of precursor gases at the urban site. Our results oppose Boulon et al. (2011) observations, who found that the nucleation process is more frequent in a high-altitude site than in a nearby urban area. Currently, the cause of the high frequency of NPF in polluted urban atmospheres, such as those in Chinese megacities, is still an open question (Kulmala et al., 2017; Yao et al., 2018).

In general, NPF event days at the SNS station seem to be connected to the events observed at the UGR station, as all the event days observed at SNS are also classified as event days in the UGR station. This results in 17 coincident event days at both sites and suggests a regional scale of NPF events. In this work, class I events have been considered when a 
Table 1. Statistical overview of daily aerosol concentrations in different size ranges in $10^{3} \mathrm{~cm}^{-3}$ at the SNS and UGR station.

\begin{tabular}{lrrrr|rrrr}
\hline & \multicolumn{4}{c}{ SNS } & \multicolumn{4}{c}{ UGR } \\
\cline { 2 - 8 } & $N_{4-25}$ & $N_{25-100}$ & $N_{100-500}$ & $N_{\text {Tot }}$ & $N_{4-25}$ & $N_{25-100}$ & $N_{100-500}$ & $N_{\text {Tot }}$ \\
\hline Minimum & 0.2 & 0.4 & 0.1 & 1.0 & 1.1 & 1.2 & 0.4 & 2.4 \\
Median & 1.3 & 1.2 & 0.4 & 3.2 & 3.8 & 3.3 & 1.0 & 9.1 \\
Maximum & 6.2 & 3.8 & 0.7 & 9.6 & 8.0 & 5.3 & 1.7 & 14.9 \\
Mean & 1.7 & 1.4 & 0.4 & 3.5 & 4.0 & 3.2 & 0.9 & 8.1 \\
SD & 1.4 & 0.9 & 0.2 & 2.3 & 1.8 & 1.2 & 0.4 & 3.2 \\
\hline
\end{tabular}

Table 2. Number of event (E), non-event (NE), or undefined (UN) NPF days and bad data (BD) observed at SNS and UGR.

\begin{tabular}{lrrrr}
\hline Site & E & NE & UN & BD \\
\hline SNS & 19 & 5 & 3 & 5 \\
UGR & 23 & 4 & 1 & 4 \\
\hline
\end{tabular}

growing mode is observed below $25 \mathrm{~nm}$, and the retrieval of GR in the 7-25 $\mathrm{nm}$ size range is possible. In this sense, at the SNS station 10 of the 19 observed events were classified as class I events, while at the UGR station 17 of the 23 observed events were classified as class I events.

It is important to note that the $\mathrm{GR}_{7-25}$ retrieval is not unambiguous for some NPF events occurring at the SNS station due to the appearance of two modes at same time in the nucleation range $(<25 \mathrm{~nm})$ during these cases (Fig. S2). These two modes are not always well separated, making the retrieval of growth and formation rates for these cases difficult or impossible. In some cases, these two modes show similar temporal evolution, but in other cases completely different behaviour is observed, suggesting different precursor vapour origin or different formation processes of both aerosol modes. The appearance of these two nucleation modes is probably associated with the advection of nucleated particles probably from lower-altitude levels (i.e. from the city of Granada) over the mountain site but also the influence of precursor gases advected over the SNS station that lead to the occurrence of NPF events at the proximities of the SNS station. In this sense, the predominant western winds at SNS during NPF events support the advection of nucleated aerosol particles and precursor gases to SNS from the valley (Fig. S3). The appearance of two modes in the nucleation size range was also observed in other mountain sites (e.g., García et al., 2014; Rose et al., 2017), and the cause for their appearance during some NPF events is an open question as remarked in the review of Sellegri et al. (2019).

While regional NPF events are usually observed after 11:00 UTC at the SNS station probably due to the upslope transport of precursor vapours from lower altitudes, at the UGR urban site, we observed the frequent occurrence of a local event (burst event) around 07:00-08:00 UTC followed by another event lasting for few hours (see Fig. S2). The first event at the urban site coincides with morning traffic rush hours and could be attributed to the so-called delayed primary particles, which are formed in the atmosphere from precursor gases released from hot vehicle exhaust after it dilutes and cools in ambient air (Rönkkö et al., 2017). This local event is followed by another event that is associated with the occurrence of regional NPF events at both stations (Fig. 3). The regional NPF events at the UGR station appear in the time range from 09:00 to 12:00 UTC, while the NPF events at the SNS station are usually observed after 11:00 UTC. It is worth mentioning that the production of $4 \mathrm{~nm}$ particles can be observed at SNS even though their production has already ended at UGR, which suggests that completely new particles are being formed at high altitudes.

\subsection{Growth and formation rate}

Figure 4a presents the box-whisker plot and time series of GRs recorded at SNS and UGR during the campaign. The $\mathrm{GR}_{7-25}$ ranges from 4.5 to $9.5 \mathrm{~nm} \mathrm{~h}^{-1}$ at $\mathrm{SNS}$, with a mean value ( \pm standard deviation) of $6.9 \pm 1.7 \mathrm{~nm} \mathrm{~h}^{-1}$, and from 2.8 to $6.2 \mathrm{~nm} \mathrm{~h}^{-1}$ at UGR, with a mean value of $4.5 \pm 1.0 \mathrm{~nm} \mathrm{~h}^{-1}$. Also, $\mathrm{GR}_{4-7}$ ranges from 3.0 to $5.9 \mathrm{~nm} \mathrm{~h}^{-1}$ at SNS, with a mean value of $4.1 \pm 0.9 \mathrm{~nm} \mathrm{~h}^{-1}$, and from 2.6 to $5.0 \mathrm{~nm} \mathrm{~h}^{-1}$ at UGR, with a mean value of $3.6 \pm 0.8 \mathrm{~nm} \mathrm{~h}^{-1}$. These values are in the range of GRs for urban and high-mountain environments reviewed by Nieminen et al. (2018) and Sellegri et al. (2019). The results show that $\mathrm{GR}_{7-25}$ and $\mathrm{GR}_{4-7}$ mean values at the SNS remote station are larger than those observed at the UGR station (Fig. 4a) and that $\mathrm{GR}_{7-25}$ is always larger at the SNS station (comparing the same NPF class I event days) (Fig. 4b). It is surprising that the growth rates, especially $\mathrm{GR}_{7-25}$, are on average larger at SNS than at UGR since higher precursor vapour concentrations are expected at the urban environment. This fact could have special importance for cloud formations, since larger GRs at the SNS mountain station could translate to a larger survival probability of NPF particles reaching $\mathrm{CCN}$ sizes, due to the shorter time period needed for the growth. However, this fact is of importance after considering that ceiling size and shrinkage are not limiting factors to reach $\mathrm{CCN}$ size. Since the ceiling of particle growth mode 

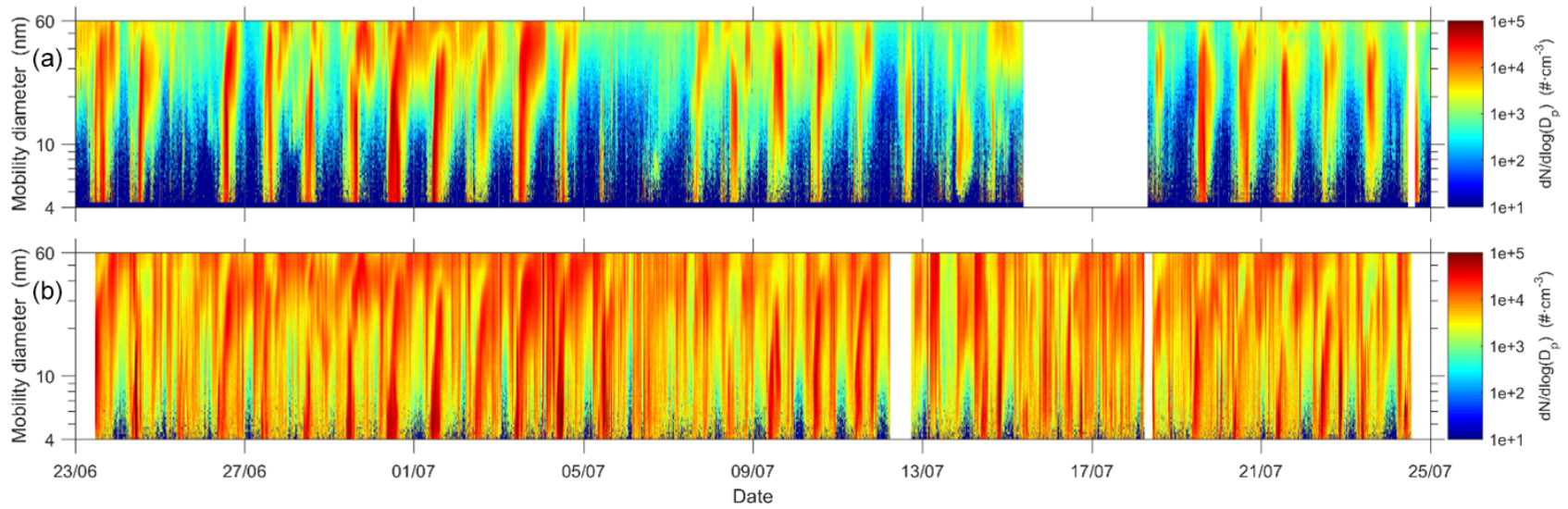

Figure 3. Size distribution time evolution from 23 June to 24 July at the SNS (a) and UGR (b) station.

ranges from 25 to $60 \mathrm{~nm}$ with a mean value of $41 \mathrm{~nm}$ during class I events at the SNS site and shrinkage has not been observed at this site, NPF events at the SNS site can affect CCN concentrations at least at high supersaturation (e.g., Fan et al., 2018; Leaitch et al., 2016; Leng et al., 2014).

Another important result is that the difference between GRs at the SNS and UGR stations is lower for the small size range, being $53 \%$ and $14 \%$ for the size range of $7-25$ and 4-7 nm, respectively. It is important to note that, although it is not a direct method, the GR at the lowest diameter ranges is a good indicator of the quantity of the condensable gases that contribute to the early growth of new particles. Thus, this result suggests that the initial steps of the aerosol formation have almost similar precursors and availability at both sites, resulting in only $14 \%$ relative difference in GR at the 4-7 $\mathrm{nm}$ range. Also, the results suggest higher differences in the available gas precursors for further steps of the aerosol growth, increasing the differences in GRs from $14 \%$ in the $4-7 \mathrm{~nm}$ range to $53 \%$ in the $7-25 \mathrm{~nm}$ range. Also, the increase in GR as a function of the particle size suggests that the growth of the particles is not only due to the same vapours that form particles through nucleation.

However, due to the difference in altitude, the differences in temperature, RH and UV-B between both stations could contribute, at least partly, to this difference in GRs between SNS and UGR. In this sense, lower temperatures at SNS than at UGR (mean temperatures of 14 and $29^{\circ} \mathrm{C}$ during event days, respectively) can decrease the evaporation rates, enhancing the effective condensation and thus particle growth at lower temperatures. $\mathrm{H}_{2} \mathrm{SO}_{4}$ is produced from the $\mathrm{SO}_{2}+$ $\mathrm{OH} \rightarrow \mathrm{SO}_{3}$ reaction, and $\mathrm{OH}$ radicals are produced from water vapour UV absorption. Thus, higher RH and UV-B radiation at SNS (mean values of $44 \%$ and $2.6 \mathrm{~W} \mathrm{~m}^{-2}$ at SNS and $21 \%$ and $2.3 \mathrm{~W} \mathrm{~m}^{-2}$ at UGR) can increase the $\mathrm{H}_{2} \mathrm{SO}_{4}$-water nucleation and $\mathrm{H}_{2} \mathrm{SO}_{4}$ production, respectively, and thus enhance particle growth, especially in the initial NPF steps. Also, as Boulon et al. (2011) and Manninen et al. (2010) pointed out, ion-mediated nucleation could be promoted at higher altitudes compared to low altitudes and therefore can contribute to the observed differences. However, as Lehtipalo et al. (2016) showed, this mechanism only accelerates the growth of newly formed particles at low concentrations of base compounds. When a strongly basic compound is present, the growth of newly formed particles can be greatly enhanced by acid-base clusters. Thus, the presence of stabilizing vapours could also be responsible for the differences observed.

Figure 5 presents the box-whisker plot and time series of the $J$ 's (formation rates, $J_{4}$ and $J_{7}$ ), showing $J_{7}$ mean values of $1.3 \pm 0.8$ and $1.1 \pm 1.2 \mathrm{~cm}^{-3} \mathrm{~s}^{-1}$ at SNS and UGR, respectively, and $J_{4}$ mean values of $2.1 \pm 1.3$ and $3.7 \pm 5.2 \mathrm{~cm}^{-3} \mathrm{~s}^{-1}$, respectively. The values of $J_{4}$ and $J_{7}$ show a large variability at both sites, ranging over 1 order of magnitude. These results differ from GR results. In this case, the $J_{4}$ mean value is $43 \%$ larger at the UGR station, while the $J_{7}$ mean value is $15 \%$ larger at the SNS station. This result differs from that reported by Nieminen et al. (2018) since $J_{7}$ is expected to be higher at stations with higher anthropogenic influence. As can be seen in Fig. 5, $\mathrm{GR}_{4-7}$ takes slightly larger values at the SNS station, and, in contrast, $J_{4}$ shows significantly larger values at the UGR station. This difference again points to the decoupling of the mechanisms leading to the initial particle formation and the subsequent growth of the particles. Also, in contrast to the particle formation rate, the particle growth rate increases as a function of particle size, suggesting the participation of other vapours than sulfuric acid. However, it is worth mentioning that the formation rate of 4 and $7 \mathrm{~nm}$ particles are not only affected by the new particle formation rate but also by the scavenging of newly formed particles by coagulation into pre-existing particles.

In order to quantify the contribution of sulfuric acid to the initial steps of the particle formation, we estimated the growth due to sulfuric acid in both 4-7 and 7-25 nm size ranges, $\mathrm{GR}_{4-7}^{\mathrm{SA}}$ and $\mathrm{GR}_{7-25}^{\mathrm{SA}}$, respectively. Figure 6 shows the resulting sulfuric acid contribution to the total experimental 

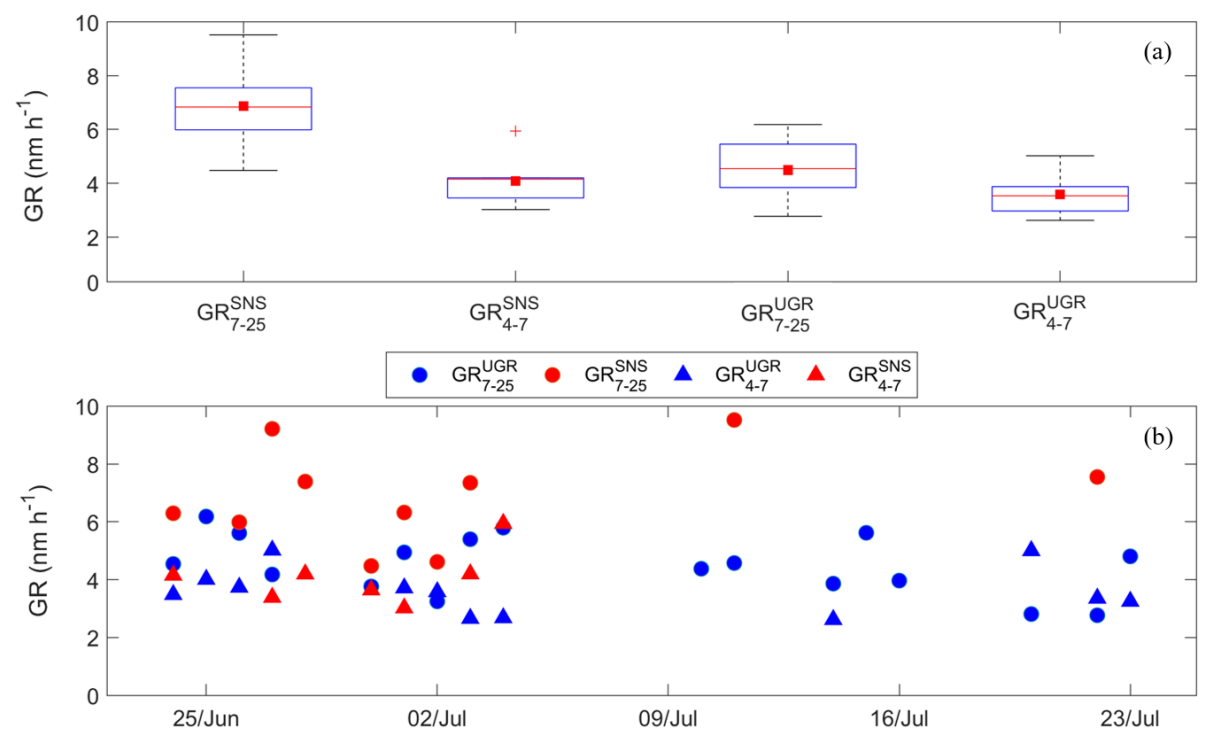

Figure 4. (a) Box and whisker plot of growth rates recorded at the SNS and UGR stations. The red line represents the median of the data, the square represents the mean of the data, and the lower and upper edges of the box represent the 25th and 75th percentiles of the data, respectively. The length of the whiskers represents the $1.5 \times$ interquartile range, which includes $99.3 \%$ of the data. (b) Growth rate time series at the SNS and UGR station.
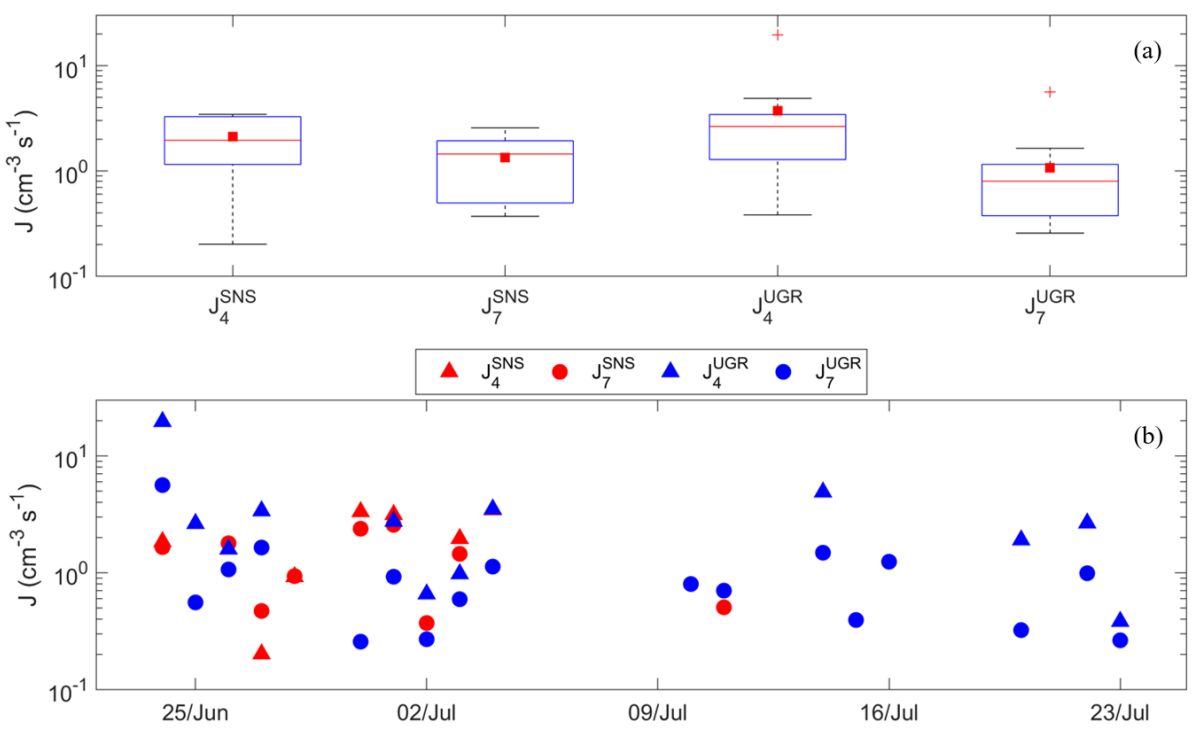

Figure 5. (a) Box and whisker plot of formation rates recorded at the SNS and UGR stations. The red line represents the median of the data, the square represents the mean of the data, and the lower and upper edges of the box represent the 25th and 75th percentiles of the data, respectively. The length of the whiskers represents the $1.5 \times$ interquartile range, which includes $99.3 \%$ of the data. (b) Formation rate time series at the SNS and UGR station.

growth rates at SNS and UGR. It is clear that sulfuric acid can only explain a small fraction of the growth rates retrieved in the ranges $4-7$ and $7-25 \mathrm{~nm}$ at both measurement sites. The ratio $\mathrm{GR}_{4-7}^{\mathrm{SA}} / \mathrm{GR}_{4-7}$ is $9 \%$ at both stations, and the ratio $\mathrm{GR}_{7-25}^{\mathrm{SA}} / \mathrm{GR}_{7-25}$ is $0.8 \%$ and $1 \%$ at SNS and UGR, respectively. Thus, sulfuric acid explains a similar small fraction of the experimental GRs at both sites during the study period, and, despite a proxy sulfuric acid concentration being used here, these results strongly suggest a significant contribution of other vapours in this period at both sites. Furthermore, despite sulfuric acid being traditionally considered as one of the main factors for NPF events to occur, $\mathrm{SO}_{2}$ and sulfuric acid concentrations are lower at SNS when events take place than on non-events days (figure not shown), indicating that sulfuric acid concentrations are sufficient for events to take place but not the factor that drives NPF events. 


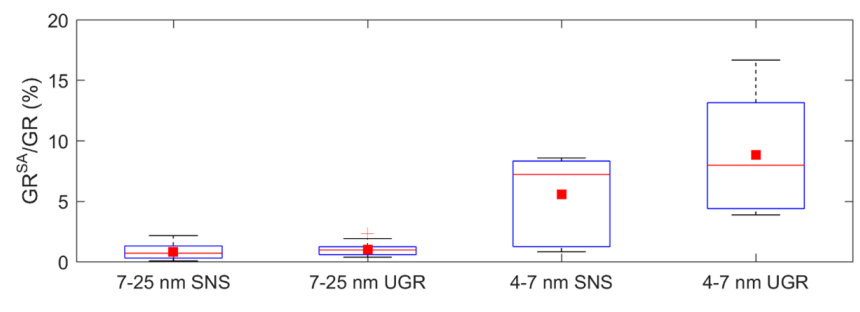

Figure 6. Box and whisker plot of sulfuric acid contribution to the total measured growth rate at SNS and UGR. The red line represents the median of the data, the square represents the mean of the data, and the lower and upper edges of the box represent the 25th and 75 th percentiles of the data, respectively. The length of the whiskers represents the $1.5 \times$ interquartile range, which includes $99.3 \%$ of the data.

Recent studies have suggested that volatile organic compounds (VOCs), especially extremely low volatility ones, play vital roles in NPF processes promoting the initial growth of newly formed particles in the atmosphere (e.g., Tröstl et al., 2016). Unfortunately, VOC measurements are not available for most of the period analysed here. However, simultaneous measurements of VOCs were recorded at SNS and UGR during a short intensive period from 15 to 30 June 2017. Surprisingly, the analysis of these measurements shows that mean VOC concentrations at the SNS remote site were higher than at the UGR urban station. Mean total VOC concentrations of 9.9 and $5.1 \mu \mathrm{g} \mathrm{m}^{-3}$ were observed at SNS and UGR, respectively, during the period 15 to 30 June. Thus, higher concentrations of VOCs at SNS, doubling approximately the UGR concentrations, could explain, at least partly, the higher growth rates observed at SNS as low-volatility vapours produced by photo-oxidation of VOCs could promote particle growth (e.g., Bianchi et al., 2019; Mohr et al., 2019).

\subsection{Condensation sink and survival parameter}

High pre-existing aerosol particle concentrations might also influence NPF events, inhibiting the process by increasing the competition for available condensable gases. In order to investigate the role of pre-existing aerosols, CS has been retrieved for the whole campaign period and averaged each day for the 09:00-12:00 UTC time interval. As expected, the average CS obtained at UGR $\left(6.7 \times 10^{-3} \mathrm{~s}^{-1}\right)$ was higher than the average value of $2.2 \times 10^{-3} \mathrm{~s}^{-1}$ obtained at SNS due to higher anthropogenic aerosol emissions close to UGR urban site. When considering event and non-event days, the CS was higher on event days (2.9 and $6.7 \times 10^{-3} \mathrm{~s}^{-1}$ at SNS and UGR, respectively) compared to non-event days (1.8 and $6.6 \times 10^{-3} \mathrm{~s}^{-1}$ at SNS and UGR, respectively), indicating that CS does not play a significant role in NPF processes at both sites. It is worth mentioning that the role of CS in NPF processes differs from one high-altitude site to another as Sellegri et al. (2019) pointed out. For example, Boulon et al. (2011) at Puy de Dôme station, Venzac et al. (2008) at the Nepal Climate Observatory Pyramid station and Lv et al. (2018) at Mount Tai found that higher CS inhibits the occurrence of NPF events. However, Boulon et al. (2010) at the Jungfraujoch station, García et al. (2014) at the Izaña station and Rose et al. (2015) at the Chacaltaya station found that higher CS observed in these sites does not inhibit the occurrence of NPF events. Overall, a detailed understanding of the role of CS in NPF events remains an open question and the chemical composition of CS could play an important role on the NPF processes (Tuovinen et al., 2020).

Looking on event days, Fig. 7 shows the relationship between $\mathrm{CS}$ and $J_{7}$ and $\mathrm{GR}_{7-25}$ at both measurement sites. As can be seen, $J_{7}$ increases with increasing $\mathrm{CS}$ at both measurement sites. This result is contrary to the expected one, since concentrations of vapours participating in NPF are expected to decrease with increasing CS due to their faster loss rate. However, this result suggests that CS and the concentrations of condensing vapours are connected. This is also supported by our previous observation showing that both CS and $\mathrm{H}_{2} \mathrm{SO}_{4}$ are higher during the NPF event days than during non-event days. On the other hand, $\mathrm{GR}_{7-25}$ tends to decrease as CS increases, especially at the SNS site (Fig. 7). Thus, this result shows that lower CS favours the growth of particles as should be expected. In this sense, as our previous results suggested, this difference in the relationship between $\mathrm{CS}$ and $J_{7}$ and $\mathrm{GR}_{7-25}$ points again to the decoupling of the mechanisms leading to the initial particle formation and the subsequent growth of the particles.

The survival probability of growing clusters links the competition between their growth and scavenging by pre-existing aerosol particles. The key parameter to estimate the clusters survival was defined by Kulmala et al. (2017) as the ratio between the CS and GR (Eq. 5). Our results show that the survival parameter $(P)$ ranges from 2 to 10 at SNS, with a mean value of $6 \pm 3$, and from 6 to 24 at UGR, with a mean value of $13 \pm 6$. At both sites, the values of $P$ are below the threshold value of 50 for NPF to take place (Kulmala et al., 2017). A larger survival parameter indicates that a smaller percentage of newly formed particles will survive to greater sizes (smaller survival probability). In this sense, lower $P$ values observed at SNS suggest that the survival probability of newly formed particles at this site is higher than at the UGR urban station.

\subsection{Case study: NPF during Saharan dust intrusion}

Mineral dust contributes to a major fraction of the global coarse mode aerosol load, with an emission rate into the atmosphere currently estimated at $1000-3000 \mathrm{Tg} \mathrm{yr}^{-1}$ from the Earth's surface (Tegen and Schepanski, 2009). Due to its proximity to the African continent, the Granada region is frequently affected by Saharan dust intrusions, especially in summer (Mandija et al., 2017; Valenzuela et al., 2015). These African dust intrusions usually transport large mineral 

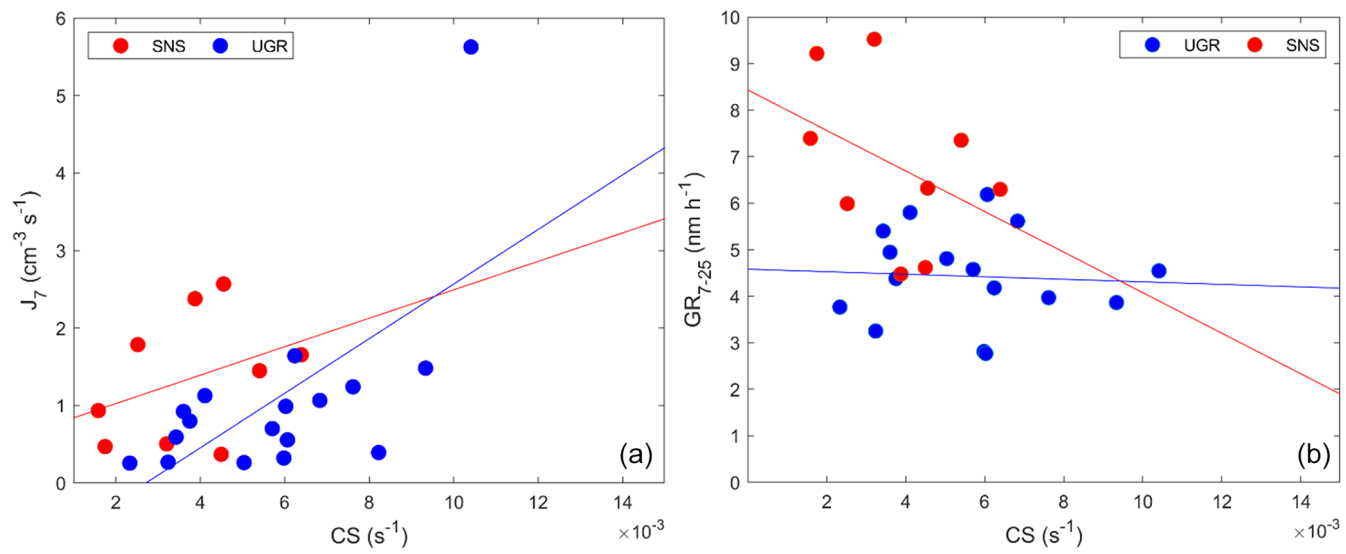

Figure 7. Relationship between CS (time window: 09:00-16:00 UTC) and $J_{7}$ (a) and $\mathrm{GR}_{7-25}$ (b) during the study period.

dust loads to our study area (e.g., Benavent-Oltra et al., 2019; Lyamani et al., 2006). During the analysed period, there was an intrusion of Saharan dust over the region of study from 24 to 27 June, as confirmed by the Calima warning system (http://www.calima.ws, last access: 15 November 2020; Fig. S4). For the confirmation of desert dust intrusions over different regions in the Iberian Peninsula, the Calima network uses information derived from different sources, including models, air mass back-trajectory analysis, synoptic meteorological charts, and satellite and surface $\mathrm{PM}_{10}$ data. As shown in Fig. 8a, there was a significant increase in the coarse particle number concentration $\left(N_{\mathrm{C}}\right.$, aerodynamic size range 1-20 $\mu \mathrm{m}$ ) during 24-27 June, supporting the presence of desert dust over the SNS station during these days. According to the $N_{\mathrm{C}}$ analysis it seems that the dust event ended around 10:00 UTC on 27 June, when $N_{\mathrm{C}}$ began to decrease, reaching concentrations similar to those observed before the dust intrusion on 23 June. Figure $8 \mathrm{~b}$ shows the $24 \mathrm{~h} \mathrm{PM}_{10}$ mass concentration (starting at 07:00 UTC) and the percentage of mineral aerosol on each measurement filter from 07:00 on 23 June to $07: 00$ on 29 June. It is worth mentioning that the last $\mathrm{PM}_{10}$ filter measurement was collected during a period of 48 h from 07:00 UTC on 27 June to 07:00 UTC on 29 June. As can be seen, $\mathrm{PM}_{10}$ mass concentrations recorded at the SNS remote station were higher than $23 \mu \mathrm{g} \mathrm{m}^{-3}$ from 24 until 27 June and after this period $\mathrm{PM}_{10}$ concentration decreases drastically to $7 \mu \mathrm{g} \mathrm{m}^{-3}$ on 27-29 June; typical background $\mathrm{PM}_{10}$ concentration is reported for European mountain sites (e.g., Dinoi et al., 2017). Also, mineral aerosol components contributed more than $65 \%$ to the total aerosol mass concentration for each measurement day, reaching the highest mineral contribution on filters 3 and 4 ( 25 and 26 June), with a relative contribution above $80 \%$ (Fig. 8b). Also, high concentrations of $\mathrm{Fe}_{2} \mathrm{O}_{3}$ and $\mathrm{Ca}$ (good tracers of desert dust aerosol) were observed (Table 3 ), confirming again the presence and the large impact of Saharan desert dust on aerosol population over our site during 24-27 June.
Table 3. Concentration of $\mathrm{Ca}, \mathrm{K}, \mathrm{Fe}_{2} \mathrm{O}_{3}$ and $\mathrm{Fe}_{2} \mathrm{O}_{3}$ during the period 23-29 June.

\begin{tabular}{lrrrrr}
\hline$\left(\mu \mathrm{g} \mathrm{m}^{-3}\right)$ & $\begin{array}{r}\text { Filter 1 } \\
\text { 23 June }\end{array}$ & $\begin{array}{r}\text { Filter 2 } \\
\text { 24 June }\end{array}$ & $\begin{array}{r}\text { Filter 3 } \\
\text { 25 June }\end{array}$ & $\begin{array}{r}\text { Filter 4 } \\
\text { 26 June }\end{array}$ & $\begin{array}{r}\text { Filter 5 } \\
\text { 27-29 June }\end{array}$ \\
\hline $\mathrm{Ca}$ & 1.05 & 0.91 & 1.22 & 0.94 & 0.46 \\
$\mathrm{~K}$ & 0.30 & 0.34 & 0.53 & 0.47 & 0.13 \\
$\mathrm{Fe}_{2} \mathrm{O}_{3}$ & 1.00 & 1.18 & 1.91 & 1.89 & 0.33 \\
$\mathrm{TiO}_{2}$ & 0.13 & 0.15 & 0.24 & 0.24 & 0.04 \\
\hline
\end{tabular}

As discussed before, high pre-existing aerosol particle loadings have been thought to suppress NPF events due to high condensation and coagulation sinks. In this sense, the NPF events are not expected to occur under desert dust episodes, especially at remote sites where the concentrations of condensable vapours are expected to be low. Also, desert dust intrusions with high concentrations of mineral dust particles are expected to reduce the concentrations of condensing vapours and the clustering by limiting solar radiation and hence photochemical oxidation of gaseous precursors, which also reduce the probability of occurrence of NPF events during desert dust events. However, although Saharan dust and NPF events are not expected to occur simultaneously at the SNS site, two NPF events classified as class I were observed at SNS on 24 and 26 June during the desert dust intrusion that occurred in the period 24 to 27 June (Fig. 8c). However, no NPF event was observed on dusty day on 25 June, although $\mathrm{PM}_{10}$ concentration on this day was similar to that registered on 24 and 26 June. Below, we will investigate the factors that promote or inhibit the occurrence of NPF events in the presence of mineral dust.

The evolution of the averaged daily CS (from 09:00 to 12:00 UTC) during these three days shows higher values on 24 June $\left(5.6 \times 10^{-3} \mathrm{~s}^{-1}\right)$, decreasing more than $40 \%$ and $70 \%$ on $25\left(3.2 \times 10^{-3} \mathrm{~s}^{-1}\right)$ and 26 June $\left(1.6 \times 10^{-3} \mathrm{~s}^{-1}\right)$, respectively. Thus, CS does not seem to be a limiting factor for the occurrence of the NPF event on 25 June (dusty 

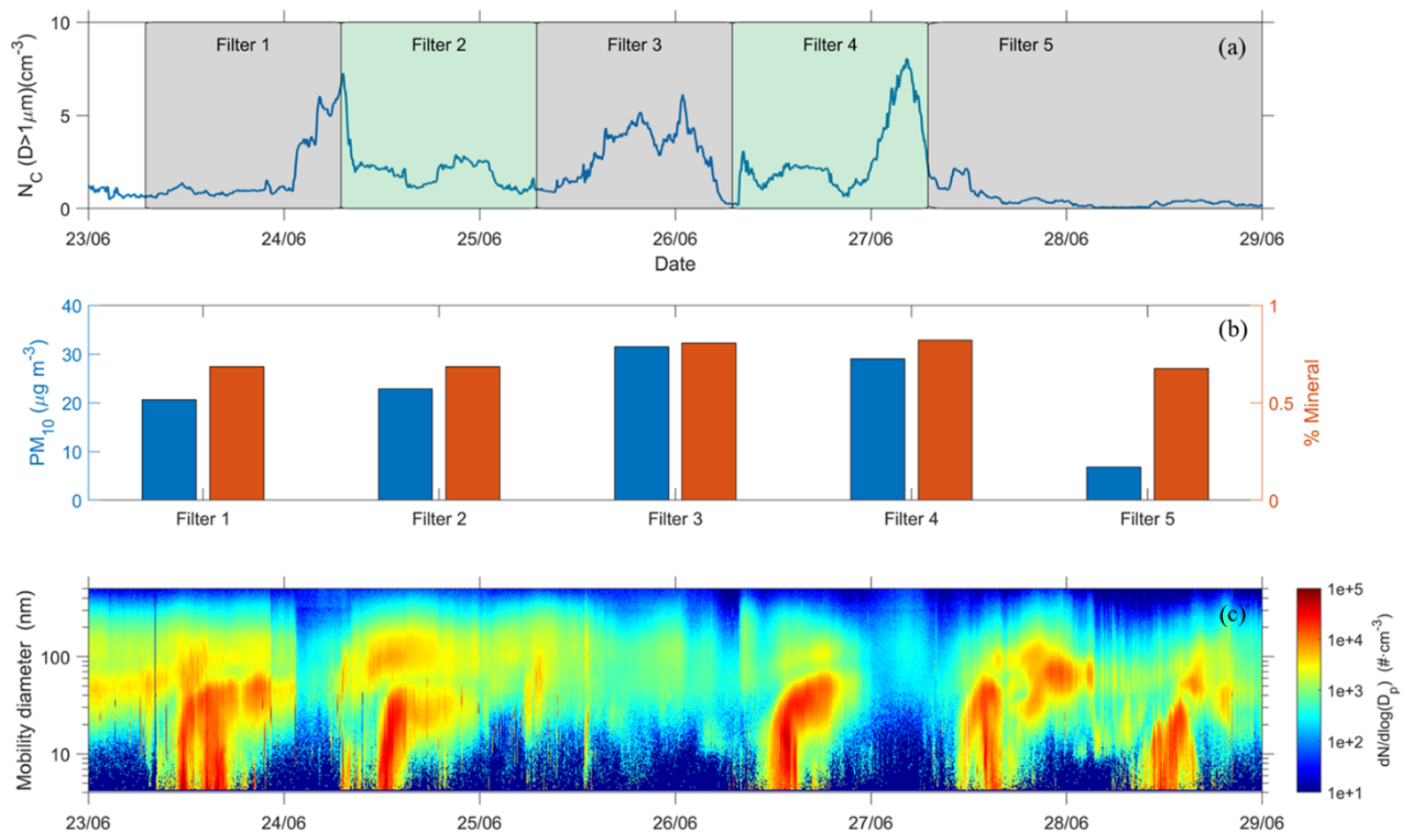

Figure 8. Temporal evolution of (a) coarse mode aerosol number concentration, (b) $\mathrm{PM}_{10}$ concentration and mineral matter fraction (\%), and (c) aerosol size distribution from 23 to 29 June at the SNS station.

day). It is important to note that, in these cases, the number concentration of coarse mode particles has been considered for CS retrievals. However, the contributions of coarse particles to the CS during these cases are below $10 \%$, because the contribution of coarse particles in the continuum regime is proportional to the particle diameter $\left(D_{\mathrm{p}}\right)$ instead of $D_{\mathrm{p}}^{2}$ (Pirjola et al., 1999).

Figure 9a shows sulfuric acid and VOCs (24 h filter sampling starting 07:00 UTC) concentrations, and Fig. 9b shows GRs and $J_{\mathrm{S}}$ retrievals at the SNS site during the 23-28 June period. The mean $J_{7}$ value of $1.72 \mathrm{~cm}^{-3} \mathrm{~s}^{-1}$ was retrieved for the two NPF events observed on 24 and 26 June dusty days. This $J_{7}$ value is slightly higher than the mean value observed for the whole campaign $\left(1.35 \mathrm{~cm}^{-3} \mathrm{~s}^{-1}\right)$, suggesting that during these dusty days there were larger production rates of condensing vapours or more favourable conditions for condensation. The opposite behaviour is found for the $\mathrm{GR}_{7-25}$, since $\mathrm{GR}_{7-25}$ value of $6.1 \mathrm{~nm} \mathrm{~h}^{-1}$ was retrieved for the two NPF events observed on 24 and 26 June, which is slightly lower (14\% relative difference) than the value observed during the overall campaign $\left(6.9 \mathrm{~nm} \mathrm{~h}^{-1}\right)$. This lower GR value obtained on NPF events on dusty days may be due to the increase in CS or to its effectiveness during dusty days, which again points to the decoupling of the mechanisms leading to the initial particle formation and the subsequent growth of the particles.
The $\mathrm{GR}_{7-25}$ shows similar values on 26 June $\left(6.0 \mathrm{~nm} \mathrm{~h}^{-1}\right)$ and 24 June $\left(6.3 \mathrm{~nm} \mathrm{~h}^{-1}\right)$. This is contrary to that expected from $\mathrm{CS}$ and $\mathrm{H}_{2} \mathrm{SO}_{4}$ concentrations. Firstly, on 26 June the CS mean value was $70 \%$ lower than on 24 June. Secondly, despite no direct measurements of sulfuric acid being available, the sulfuric acid concentration estimated by proxy on 26 June $\left(4.0 \times 10^{7} \mathrm{molec}^{-3}\right)$ was 3 times higher than on 24 June $\left(1.3 \times 10^{7} \mathrm{molec}^{-3}\right)$. As discussed before, the estimated concentrations of sulfuric acid could only explain less than $10 \%$ of the observed GRs. These results evidence the fact that sulfuric acid and CS do not play a relevant role in the particle growth during the NPF events observed during these dusty days. However, the significantly high VOC concentration observed on 24 June $\left(8.4 \mu \mathrm{g} \mathrm{m}^{-3}\right)$ as compared to 26 June $\left(5.4 \mu \mathrm{g} \mathrm{m}^{-3}\right)$ can explain at least partly the differences observed on GR from 24 to 26 June.

Furthermore, the results suggest that sulfuric acid is not a limiting factor for the occurrence of the NPF event on the 25 June dusty day, since an increase on sulfuric acid concentrations is observed from 24 to 25 June (Fig. 9a). However, as can be seen in Fig. 9a, VOC concentration showed a decrease by $\sim 67 \%$ from 24 to 25 June. The significant reduction of VOC concentrations on 25 June could be a possible factor limiting the occurrence of NPF on this dusty day. Thus, the results point to VOCs as one of the main driving factors controlling the occurrence of the NPF event and subsequent particle growth at the SNS site during Saharan dust events. 

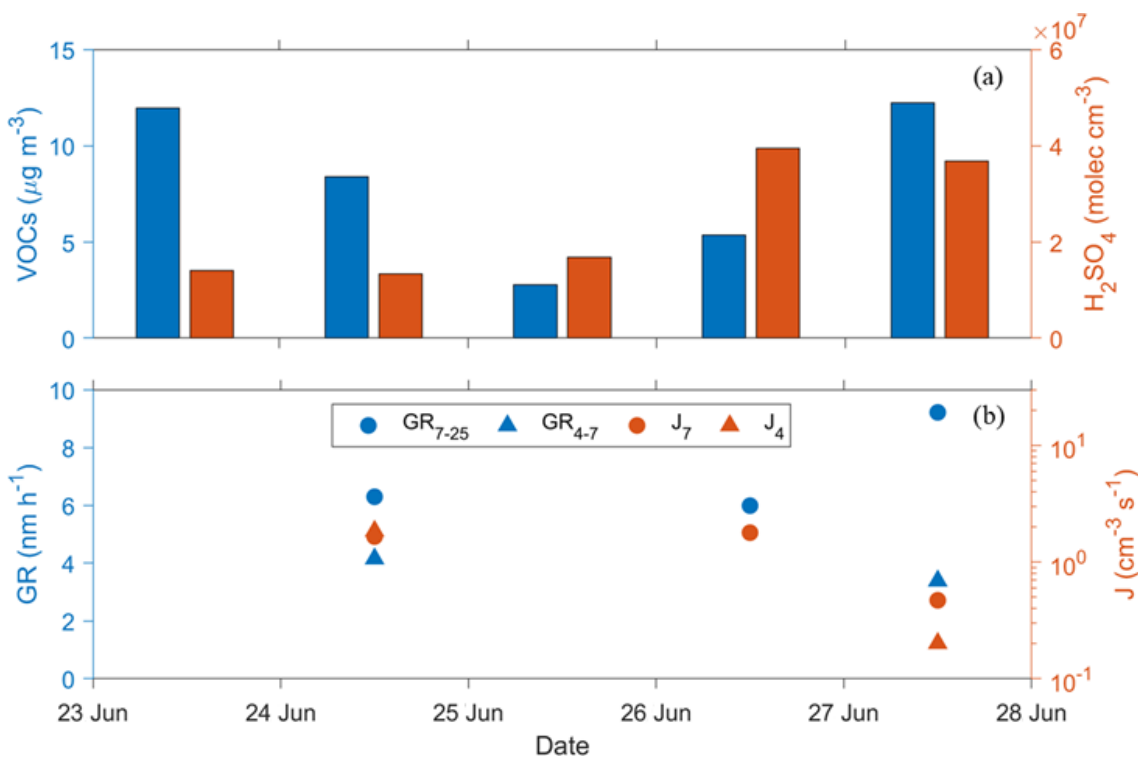

Figure 9. (a) VOCs and $\mathrm{H}_{2} \mathrm{SO}_{4}$ concentration and (b) GR and $J$ in different size ranges from 23 to 28 June observed at the SNS station.

Finally, the chemical composition of desert dust particles (acting as CS) may be another important factor that can play a significant role in the occurrence of NPF events during dust events. In fact, recent laboratory and observational studies (Dupart et al., 2012; Nie et al., 2014) revealed that the presence of $\mathrm{TiO}_{2}$ and $\mathrm{Fe}_{2} \mathrm{O}_{3}$ (which are common components of mineral dust) under UV light could promote the occurrence of NPF and can enhance the formation of $\mathrm{OH}$ and other radicals that favour oxidation reactions, promoting the occurrence of NPF during dusty conditions. These components, acting as catalysts, are not consumed in the photo-catalytic reaction and can accelerate atmospheric photochemistry repeatedly. The $\mathrm{PM}_{10}$ elemental analysis shows that both components reached their highest concentrations on 25 and 26 June, with $\mathrm{TiO}_{2}$ concentrations of $0.24 \mu \mathrm{g} \mathrm{m}^{-3}$ on both days and $\mathrm{F}_{2} \mathrm{O}_{3}$ concentrations of 1.91 and $1.89 \mu \mathrm{g} \mathrm{m}^{-3}$ on 25 and 26 June, respectively (Table 3 ). It is worth noting that the effectiveness of photochemical reactions in promoting the occurrence of NPF depends largely on the available precursor gases. Thus, the increased $\mathrm{TiO}_{2}$ and $\mathrm{F}_{2} \mathrm{O}_{3}$ concentrations, together with the high concentrations of $\mathrm{H}_{2} \mathrm{SO}_{4}$ and VOCs observed on 26 June, could explain, at least partly, the occurrence of NPF and the observed high formation rates during this dusty day (26 June). However, although the concentrations of $\mathrm{TiO}_{2}$ and $\mathrm{F}_{2} \mathrm{O}_{3}$ on 25 June (non-event day) were high and comparable to those observed on 26 June, the low availability of precursor gases on this dusty day seems to be the cause of the non-occurrence of the NPF event. Summarizing, these findings suggest that $\mathrm{TiO}_{2}$ and $\mathrm{Fe}_{2} \mathrm{O}_{3}$ could promote NPF events during dusty conditions, but the availability of VOCs seems to be the main factor controlling the occurrence of NPF events in this area. To improve our under- standing in this topic, further investigation accompanied by multiplatform measurement campaigns is needed.

\section{Summary and conclusions}

We investigated the aerosol size distribution at two stations located close to each other $(\sim 20 \mathrm{~km})$ but at different altitudes: urban (UGR; $680 \mathrm{~m}$ a.s.l.) and high-altitude remote (SNS; $2500 \mathrm{~m}$ a.s.l.) sites, both in the area of Granada (Spain) and part of AGORA observatory (Andalusian Global ObseRvatory of the Atmosphere). Our results show the important contribution of nucleation mode aerosols to the total particle number concentration at both sites, with a contribution of $47 \%$ and $48 \%$ at SNS and UGR, respectively. Despite the SNS remote site being less influenced by anthropogenic emissions, the temporal evolution of aerosol total concentration shows larger concentrations at the SNS site during some days, associated with high concentrations of nucleation mode particles.

New particle formation (NPF) events were studied in detail due to their high frequency of occurrence ( $>70 \%$ at both sites) and their significant contributions to total aerosol number concentrations. Our analysis suggests that NPF events at the SNS remote site are associated with the transport of precursor vapours from lower altitudes by orographic buoyant upward flows. NPF events at the SNS site are always observed from the smallest measured sizes of the aerosol size distribution $(4 \mathrm{~nm})$, implying that NPF takes place at or in the vicinity of the high-altitude SNS station rather than being transported from lower altitudes. However, despite the connection between the occurrence of NPF events at the mountain and urban site, different growth rates (GRs) were ob- 
served at both stations; the GRs at the SNS site were larger than those at the UGR site $\left(\mathrm{GR}_{7-25}\right.$ of 6.9 and $4.5 \mathrm{~nm} \mathrm{~h}^{-1}$ and $\mathrm{GR}_{4-7}$ of 4.1 and $3.6 \mathrm{~nm} \mathrm{~h}^{-1}$ at SNS and UGR, respectively). This fact could have special importance for the production of cloud condensation nuclei $(\mathrm{CCN})$ and therefore for cloud formations which may affect regional/global climate, since larger GRs at mountain sites could translate to a larger survival probability of NPF particles reaching CCN sizes, due to the shorter time period needed for the growth. The increase in GR differences between SNS and UGR with increasing size (increasing from $14 \%$ in the size range of 4 $7 \mathrm{~nm}$ to $53 \%$ in the range $7-25 \mathrm{~nm}$ ) suggests higher concentrations of the available gas precursors, other than sulfuric acid, for further steps of the aerosol growth. This was also supported by the low contribution of sulfuric acid to the observed GRs at both sites $(<1 \%$ and $<10 \%$ for the $7-25$ and 4-7 nm size range, respectively). A deep analysis of the role of precursor gases in NPF processes points to the volatile organic compounds (VOCs) as one of the main factors controlling the NPF events at both sites.

Higher condensation sink (CS) values on event days compared to non-event days were observed at both measurement sites, suggesting that CS is not the limiting factor of NPF processes at either of the sites. In fact, the obtained results suggest that the availability of condensable vapours at SNS is closely connected to CS. In this sense, although Saharan dust and NPF events are not expected to occur simultaneously at the SNS remote site, two NPF events were identified during an intrusion of Saharan dust. A close analysis of these two NPF events suggests that $\mathrm{TiO}_{2}$ and $\mathrm{Fe}_{2} \mathrm{O}_{3}$ could promote NPF events, but the availability of VOCs seems to be the main factor controlling the occurrence of NPF events during dusty conditions. Despite further investigation being needed to improve our understanding in this topic, this result suggests that climate effects of mineral dust and NPF are not disconnected from each other as it was commonly thought. Therefore, since mineral dust contributes to a major fraction of the global aerosol mass load, dust-NPF interaction should be taken into account in global aerosol-climate modelling for better climate change prediction.

Data availability. The data used in the manuscript is available from the first author at casquero@ugr.es.

Supplement. The supplement related to this article is available online at: https://doi.org/10.5194/acp-20-14253-2020-supplement.

Author contributions. JACV analysed the data and wrote the manuscript. JACV and HL operated and processed the in situ measurement, and RR operated and processed the UV-B measurements. LD, SH and PP helped with the pre-processing of the raw data and provided feedback on the NPF analysis and the MATLAB code.
LD, SH, PP and TP provided useful discussion and ideas. The formal analysis, investigation, writing of the original draft, preparation, review of the writing and editing were performed by JACV, $\mathrm{HL}$ and LAA. The project administration and funding acquisition were done by FJOR and LAA. All authors provided comments on the manuscript and helped with the correction of the paper.

Competing interests. The authors declare that they have no conflict of interest.

Acknowledgements. Juan Andrés Casquero-Vera is funded by MINECO under predoctoral programme FPI (BES-2017-080015). Simo Hakala acknowledges the doctoral programme in atmospheric sciences (ATM-DP, University of Helsinki) for financial support. The authors thankfully acknowledge the FEDER programme for the instrumentation used in this work and the University of Granada, which supported this study through the excellence units programme. The authors would like to thank the Air Quality Service from Junta de Andalucía (Consejería de Medio Ambiente y Ordenación del Territorio), University of Évora, Fundación CEAM and TSI for their support during the SLOPE II campaign.

Financial support. This research has been supported by the Spanish Ministry of Economy and Competitiveness (grant nos. BES2017-080015, CGL2016-81092-R, CGL2017-90884-REDT and RTI2018-097864-B-I00), the Andalusian Regional Government (grant no. P18-RT-3820), the European Union (grant nos. 654109, 871115 and 689443), and the Academy of Finland (grant nos. 311932, 307537, 328616 and 329274).

Review statement. This paper was edited by Xavier Querol and reviewed by two anonymous referees.

\section{References}

Benavent-Oltra, J. A., Román, R., Casquero-Vera, J. A., PérezRamírez, D., Lyamani, H., Ortiz-Amezcua, P., BedoyaVelásquez, A. E., de Arruda Moreira, G., Barreto, Á., Lopatin, A., Fuertes, D., Herrera, M., Torres, B., Dubovik, O., GuerreroRascado, J. L., Goloub, P., Olmo-Reyes, F. J., and AladosArboledas, L.: Different strategies to retrieve aerosol properties at night-time with the GRASP algorithm, Atmos. Chem. Phys., 19, 14149-14171, https://doi.org/10.5194/acp-19-141492019, 2019.

Bianchi, F., Tröstl, J., Junninen, H., Frege, C., Henne, S., Hoyle, C. R., Molteni, U., Herrmann, E., Adamov, A., Bukowiecki, N., Chen, X., Duplissy, J., Gysel, M., Hutterli, M., Kangasluoma, J., Kontkanen, J., Kürten, A., Manninen, H. E., Münch, S., Peräkylä, O., Petäjä, T., Rondo, L., Williamson, C., Weingartner, E., Curtius, J., Worsnop, D. R., Kulmala, M., Dommen, J., and Baltensperger, U.: New particle formation in the free troposphere: A question of chemistry and timing, Science, 352, 1109-1112, https://doi.org/10.1126/science.aad5456, 2016. 
Bianchi, F., Kurtén, T., Riva, M., Mohr, C., Rissanen, M. P., Roldin, P., Berndt, T., Crounse, J. D., Wennberg, P. O., Mentel, T. F., Wildt, J., Junninen, H., Jokinen, T., Kulmala, M., Worsnop, D. R., Thornton, J. A., Donahue, N., Kjaergaard, H. G., and Ehn, M.: Highly Oxygenated Organic Molecules (HOM) from GasPhase Autoxidation Involving Peroxy Radicals: A Key Contributor to Atmospheric Aerosol, Chem. Rev., 119, 3472-3509, https://doi.org/10.1021/acs.chemrev.8b00395, 2019.

Birmili, W., Weinhold, K., Rasch, F., Sonntag, A., Sun, J., Merkel, M., Wiedensohler, A., Bastian, S., Schladitz, A., Löschau, G., Cyrys, J., Pitz, M., Gu, J., Kusch, T., Flentje, H., Quass, U., Kaminski, H., Kuhlbusch, T. A. J., Meinhardt, F., Schwerin, A., Bath, O., Ries, L., Gerwig, H., Wirtz, K., and Fiebig, M.: Longterm observations of tropospheric particle number size distributions and equivalent black carbon mass concentrations in the German Ultrafine Aerosol Network (GUAN), Earth Syst. Sci. Data, 8, 355-382, https://doi.org/10.5194/essd-8-355-2016, 2016.

Borrás, E.: Caracterización de material particulado atmosférico generado en reactores fotoquímicos y procedente de muestras ambientales, Universitat Politècnica de València, Spain, available at: https://dialnet.unirioja.es/servlet/tesis?codigo=83384 (last access: 15 November 2020), 2013.

Boulon, J., Sellegri, K., Hervo, M., Picard, D., Pichon, J.-M., Fréville, P., and Laj, P.: Investigation of nucleation events vertical extent: a long term study at two different altitude sites, Atmos. Chem. Phys., 11, 5625-5639, https://doi.org/10.5194/acp11-5625-2011, 2011.

Carnerero, C., Pérez, N., Reche, C., Ealo, M., Titos, G., Lee, H.K., Eun, H.-R., Park, Y.-H., Dada, L., Paasonen, P., Kerminen, V.-M., Mantilla, E., Escudero, M., Gómez-Moreno, F. J., Alonso-Blanco, E., Coz, E., Saiz-Lopez, A., Temime-Roussel, B., Marchand, N., Beddows, D. C. S., Harrison, R. M., Petäjä, T., Kulmala, M., Ahn, K.-H., Alastuey, A., and Querol, X.: Vertical and horizontal distribution of regional new particle formation events in Madrid, Atmos. Chem. Phys., 18, 16601-16618, https://doi.org/10.5194/acp-18-16601-2018, 2018.

Casquero-Vera, J. A., Lyamani, H., Titos, G., Borrás, E., Olmo, F. J. and Alados-Arboledas, L.: Impact of primary $\mathrm{NO}_{2}$ emissions at different urban sites exceeding the European $\mathrm{NO}_{2}$ standard limit, Sci. Total Environ., 646, 1117-1125, https://doi.org/10.1016/j.scitotenv.2018.07.360, 2019.

Chu, B., Kerminen, V.-M., Bianchi, F., Yan, C., Petäjä, T., and Kulmala, M.: Atmospheric new particle formation in China, Atmos. Chem. Phys., 19, 115-138, https://doi.org/10.5194/acp-19-1152019, 2019.

Crumeyrolle, S., Manninen, H. E., Sellegri, K., Roberts, G., Gomes, L., Kulmala, M., Weigel, R., Laj, P., and Schwarzenboeck, A.: New particle formation events measured on board the ATR-42 aircraft during the EUCAARI campaign, Atmos. Chem. Phys., 10, 6721-6735, https://doi.org/10.5194/acp-106721-2010, 2010.

Dada, L., Paasonen, P., Nieminen, T., Buenrostro Mazon, S., Kontkanen, J., Peräkylä, O., Lehtipalo, K., Hussein, T., Petäjä, T., Kerminen, V.-M., Bäck, J., and Kulmala, M.: Long-term analysis of clear-sky new particle formation events and nonevents in Hyytiälä, Atmos. Chem. Phys., 17, 6227-6241, https://doi.org/10.5194/acp-17-6227-2017, 2017.

Dal Maso, M., Kulmala, M., Riipinen, I., Wagner, R., Hussein, T., Aalto, P. P., and Lehtinen, K. E. J.: Formation and growth of fresh atmospheric aerosols: Eight years of aerosol size distribution data from SMEAR II, Hyytiälä, Finland, Boreal Environ. Res., 10, 323-336, 2005.

Dameto de España, C., Wonaschütz, A., Steiner, G., Rosati, B., Demattio, A., Schuh, H., and Hitzenberger, R.: Long-term quantitative field study of New Particle Formation (NPF) events as a source of Cloud Condensation Nuclei $(\mathrm{CCN})$ in the urban background of Vienna, Atmos. Environ., 164, 289-298, https://doi.org/10.1016/j.atmosenv.2017.06.001, 2017.

Dinoi, A., Cesari, D., Marinoni, A., Bonasoni, P., Riccio, A., Chianese, E., Tirimberio, G., Naccarato, A., Sprovieri, F., Andreoli, V., Moretti, S., Gullì, D., Calidonna, C. R., Ammoscato, I., and Contini, D.: Inter-comparison of carbon content in $\mathrm{PM}_{2.5}$ and $\mathrm{PM}_{10}$ collected at five measurement sites in Southern Italy, Atmosphere, 8, 243, https://doi.org/10.3390/atmos8120243, 2017.

Dupart, Y., King, S. M., Nekat, B., Nowak, A., Wiedensohler, A., Herrmann, H., David, G., Thomas, B., Miffre, A., Rairoux, P., D'Anna, B., and George, C.: Mineral dust photochemistry induces nucleation events in the presence of $\mathrm{SO}_{2}$, P. Natl. Acad. Sci. USA, 109, 20842-20847, https://doi.org/10.1073/pnas.1212297109, 2012.

Ehn, M., Thornton, J. A., Kleist, E., Sipilä, M., Junninen, H., Pullinen, I., Springer, M., Rubach, F., Tillmann, R., Lee, B., Lopez-Hilfiker, F., Andres, S., Acir, I. H., Rissanen, M., Jokinen, T., Schobesberger, S., Kangasluoma, J., Kontkanen, J., Nieminen, T., Kurtén, T., Nielsen, L. B., Jørgensen, S., Kjaergaard, H. G., Canagaratna, M., Maso, M. D., Berndt, T., Petäjä, T., Wahner, A., Kerminen, V. M., Kulmala, M., Worsnop, D. R., Wildt, J., and Mentel, T. F.: A large source of lowvolatility secondary organic aerosol, Nature, 506, 476-479, https://doi.org/10.1038/nature13032, 2014.

Fan, J., Rosenfeld, D., Zhang, Y., Giangrande, S. E., Li, Z., Machado, L. A. T., Martin, S. T., Yang, Y., Wang, J., Artaxo, P., Barbosa, H. M. J., Braga, R. C., Comstock, J. M., Feng, Z., Gao, W., Gomes, H. B., Mei, F., Pöhlker, C., Pöhlker, M. L., Pöschl, U., and De Souza, R. A. F.: Substantial convection and precipitation enhancements by ultrafine aerosol particles, Science, 359, 411-418, https://doi.org/10.1126/science.aan8461, 2018.

Foucart, B., Sellegri, K., Tulet, P., Rose, C., Metzger, J.-M., and Picard, D.: High occurrence of new particle formation events at the Maïdo high-altitude observatory (2150 m), Réunion (Indian Ocean), Atmos. Chem. Phys., 18, 9243-9261, https://doi.org/10.5194/acp-18-9243-2018, 2018.

Fuchs, N. A. and Sutugin, A. G.: High-Dispersed Aerosols, in: Topics in Current Aerosol Research, Topics in Current Aerosol Research, Pergamon, https://doi.org/10.1016/B978-0-08-0166742.50006-6.p, p 1, 1971

García, M. I., Rodríguez, S., González, Y., and García, R. D.: Climatology of new particle formation at Izaña mountain GAW observatory in the subtropical North Atlantic, Atmos. Chem. Phys., 14, 3865-3881, https://doi.org/10.5194/acp-14-3865-2014, 2014.

Gómez-Moreno, F. J., Pujadas, M., Plaza, J., Rodríguez-Maroto, J. J., Martínez-Lozano, P., and Artíñano, B.: Influence of seasonal factors on the atmospheric particle number concentration and size distribution in Madrid, Atmos. Environ., 45, 3169-3180, https://doi.org/10.1016/j.atmosenv.2011.02.041, 2011.

Hama, S. M. L., Cordell, R. L., Kos, G. P. A., Weijers, E. P., and Monks, P. S.: Sub-micron particle number size distribution char- 
acteristics at two urban locations in Leicester, Atmos. Res., 194, 1-16, https://doi.org/10.1016/j.atmosres.2017.04.021, 2017.

Hamburger, T., McMeeking, G., Minikin, A., Birmili, W., Dall'Osto, M., O'Dowd, C., Flentje, H., Henzing, B., Junninen, H., Kristensson, A., de Leeuw, G., Stohl, A., Burkhart, J. F., Coe, H., Krejci, R., and Petzold, A.: Overview of the synoptic and pollution situation over Europe during the EUCAARILONGREX field campaign, Atmos. Chem. Phys., 11, 10651082, https://doi.org/10.5194/acp-11-1065-2011, 2011.

Hussein, T., Dal Maso, M., Petäjä, T., Koponen, I. K., Paatero, P., Aalto, P. P., Hämeri, K., and Kulmala, M.: Evaluation of an automatic algorithm for fitting the particle number size distributions, Boreal Environ. Res., 10, 337-355, 2005.

Kerminen, V.-M., Paramonov, M., Anttila, T., Riipinen, I., Fountoukis, C., Korhonen, H., Asmi, E., Laakso, L., Lihavainen, H., Swietlicki, E., Svenningsson, B., Asmi, A., Pandis, S. N., Kulmala, M., and Petäjä, T.: Cloud condensation nuclei production associated with atmospheric nucleation: a synthesis based on existing literature and new results, Atmos. Chem. Phys., 12, $12037-$ 12059, https://doi.org/10.5194/acp-12-12037-2012, 2012.

Kerminen, V. M., Chen, X., Vakkari, V., Petäjä, T., Kulmala, M., and Bianchi, F.: Atmospheric new particle formation and growth: Review of field observations, Environ. Res. Lett., 13, https://doi.org/10.1088/1748-9326/aadf3c, 2018.

Komppula, M., Lihavainen, H., Hatakka, J., Paatero, J., Aalto, P., Kulmala, M., and Viisanen, Y.: Observations of new particle formation and size distributions at two different heights and surroundings in subarctic area in northern Finland, J. Geophys. Res.Atmos., 108, 4295, https://doi.org/10.1029/2002jd002939, 2003.

Kulmala, M. and Kerminen, V. M.: On the formation and growth of atmospheric nanoparticles, Atmos. Res., 90, 132-150, https://doi.org/10.1016/j.atmosres.2008.01.005, 2008.

Kulmala, M., Dal Maso, M., Mäkelä, J. M., Pirjola, L., Väkevä, M., Aalto, P., Miikkulainen, P., Hämeri, K., and O'Dowd, C. D.: On the formation, growth and composition of nucleation mode particles, Tellus B, 53, 479-490, https://doi.org/10.3402/tellusb.v53i4.16622, 2001.

Kulmala, M., Vehkamäki, H., Petäjä, T., Dal Maso, M., Lauri, A., Kerminen, V. M., Birmili, W., and McMurry, P. H.: Formation and growth rates of ultrafine atmospheric particles: A review of observations, J. Aerosol Sci., 35, 143-176, https://doi.org/10.1016/j.jaerosci.2003.10.003, 2004.

Kulmala, M., Petäjä, T., Nieminen, T., Sipilä, M., Manninen, H. E., Lehtipalo, K., Dal Maso, M., Aalto, P. P., Junninen, H., Paasonen, P., Riipinen, I., Lehtinen, K. E. J., Laaksonen, A., and Kerminen, V. M.: Measurement of the nucleation of atmospheric aerosol particles, Nat. Protoc., 7), 1651-1667, https://doi.org/10.1038/nprot.2012.091, 2012.

Kulmala, M., Kontkanen, J., Junninen, H., Lehtipalo, K., Manninen, H. E., Nieminen, T., Petäjä, T., Sipilä, M., Schobesberger, S., Rantala, P., Franchin, A., Jokinen, T., Järvinen, E., Äijälä, M., Kangasluoma, J., Hakala, J., Aalto, P. P., Paasonen, P., Mikkilä, J., Vanhanen, J., Aalto, J., Hakola, H., Makkonen, U., Ruuskanen, T., Mauldin, R. L., Duplissy, J., Vehkamäki, H., Bäck, J., Kortelainen, A., Riipinen, I., Kurtén, T., Johnston, M. V., Smith, J. N., Ehn, M., Mentel, T. F., Lehtinen, K. E. J., Laaksonen, A., Kerminen, V. M., and Worsnop, D. R.: Direct observations of atmospheric aerosol nucleation, Science, 339, 943-946, https://doi.org/10.1126/science.1227385, 2013.
Kulmala, M., Petäjä, T., Ehn, M., Thornton, J., Sipilä, M., Worsnop, D. R., and Kerminen, V.-M.: Chemistry of Atmospheric Nucleation: On the Recent Advances on Precursor Characterization and Atmospheric Cluster Composition in Connection with Atmospheric New Particle Formation, Annu. Rev. Phys. Chem., 65, 21-37, https://doi.org/10.1146/annurev-physchem-040412$110014,2014$.

Kulmala, M., Kerminen, V. M., Petäjä, T., Ding, A. J., and Wang, L.: Atmospheric gas-to-particle conversion: Why NPF events are observed in megacities?, Faraday Discuss., 200, 271-288, https://doi.org/10.1039/c6fd00257a, 2017.

Kurtén, T., Noppel, M., Vehkamäki, H., Salonen, M., and Kulmala, M.: Quantum chemical studies of hydrate formation of $\mathrm{H}_{2} \mathrm{SO}_{4}$ and $\mathrm{HSO}_{4}^{-}$, Boreal Environ. Res., 12, 431-453, 2007.

Leaitch, W. R., Korolev, A., Aliabadi, A. A., Burkart, J., Willis, M. D., Abbatt, J. P. D., Bozem, H., Hoor, P., Köllner, F., Schneider, J., Herber, A., Konrad, C., and Brauner, R.: Effects of $20-100 \mathrm{~nm}$ particles on liquid clouds in the clean summertime Arctic, Atmos. Chem. Phys., 16, 11107-11124, https://doi.org/10.5194/acp-16-11107-2016, 2016.

Lehtipalo, K., Rondo, L., Kontkanen, J., Schobesberger, S., Jokinen, T., Sarnela, N., Kürten, A., Ehrhart, S., Franchin, A., Nieminen, T., Riccobono, F., Sipilä, M., Yli-Juuti, T., Duplissy, J., Adamov, A., Ahlm, L., Almeida, J., Amorim, A., Bianchi, F., Breitenlechner, M., Dommen, J., Downard, A. J., Dunne, E. M., Flagan, R. C., Guida, R., Hakala, J., Hansel, A., Jud, W., Kangasluoma, J., Kerminen, V. M., Keskinen, H., Kim, J., Kirkby, J., Kupc, A., Kupiainen-Määttä, O., Laaksonen, A., Lawler, M. J., Leiminger, M., Mathot, S., Olenius, T., Ortega, I. K., Onnela, A., Petäjä, T., Praplan, A., Rissanen, M. P., Ruuskanen, T., Santos, F. D., Schallhart, S., Schnitzhofer, R., Simon, M., Smith, J. N., Tröstl, J., Tsagkogeorgas, G., Tomé, A., Vaattovaara, P., Vehkamäki, H., Vrtala, A. E., Wagner, P. E., Williamson, C., Wimmer, D., Winkler, P. M., Virtanen, A., Donahue, N. M., Carslaw, K. S., Baltensperger, U., Riipinen, I., Curtius, J., Worsnop, D. R., and Kulmala, M.: The effect of acid-base clustering and ions on the growth of atmospheric nano-particles, Nat. Commun., 7, 11594, https://doi.org/10.1038/ncomms11594, 2016.

Leng, C., Zhang, Q., Tao, J., Zhang, H., Zhang, D., Xu, C., Li, X., Kong, L., Cheng, T., Zhang, R., Yang, X., Chen, J., Qiao, L., Lou, S., Wang, H., and Chen, C.: Impacts of new particle formation on aerosol cloud condensation nuclei (CCN) activity in Shanghai: case study, Atmos. Chem. Phys., 14, 11353-11365, https://doi.org/10.5194/acp-14-11353-2014, 2014.

Lv, G., Sui, X., Chen, J., Jayaratne, R., and Mellouki, A.: Investigation of new particle formation at the summit of Mt. Tai, China, Atmos. Chem. Phys., 18, 2243-2258, https://doi.org/10.5194/acp-18-2243-2018, 2018.

Lyamani, H., Olmo, F. J., Alcántara, A., and Alados-Arboledas, L.: Atmospheric aerosols during the 2003 heat wave in southeastern Spain I: Spectral optical depth, Atmos. Environ., 40, 6453-6464, https://doi.org/10.1016/j.atmosenv.2006.04.048, 2006.

Lyamani, H., Olmo, F. J., and Alados-Arboledas, L.: Physical and optical properties of aerosols over an urban location in Spain: seasonal and diurnal variability, Atmos. Chem. Phys., 10, 239254, https://doi.org/10.5194/acp-10-239-2010, 2010.

Lyamani, H., Olmo, F. J., Foyo, I., and Alados-Arboledas, L.: Black carbon aerosols over an urban area in south-eastern Spain: Changes detected after the 2008 
economic crisis, Atmos. Environ., 45, 6423-6432, https://doi.org/10.1016/j.atmosenv.2011.07.063, 2011.

Mandija, F., Sicard, M., Comerón, A., Alados-Arboledas, L., Guerrero-Rascado, J. L., Bravo-Aranda, J. A., Bravo-Aranda, J. A., Granados-Muñoz, M. J., Lyamani, H., Muñoz Porcar, C., Rocadenbosch, F., Rodríguez, A., Valenzuela, A., and García Vizcaíno, D.: Origin and pathways of the mineral dust transport to two Spanish EARLINET sites: Effect on the observed columnar and range-resolved dust optical properties, Atmos. Res., 187, 69-83, https://doi.org/10.1016/j.atmosres.2016.12.002, 2017.

Manninen, H. E., Nieminen, T., Asmi, E., Gagné, S., Häkkinen, S., Lehtipalo, K., Aalto, P., Vana, M., Mirme, A., Mirme, S., Hõrrak, U., Plass-Dülmer, C., Stange, G., Kiss, G., Hoffer, A., Törő, N., Moerman, M., Henzing, B., de Leeuw, G., Brinkenberg, M., Kouvarakis, G. N., Bougiatioti, A., Mihalopoulos, N., O’Dowd, C., Ceburnis, D., Arneth, A., Svenningsson, B., Swietlicki, E., Tarozzi, L., Decesari, S., Facchini, M. C., Birmili, W., Sonntag, A., Wiedensohler, A., Boulon, J., Sellegri, K., Laj, P., Gysel, M., Bukowiecki, N., Weingartner, E., Wehrle, G., Laaksonen, A., Hamed, A., Joutsensaari, J., Petäjä, T., Kerminen, V.-M., and Kulmala, M.: EUCAARI ion spectrometer measurements at 12 European sites - analysis of new particle formation events, Atmos. Chem. Phys., 10, 7907-7927, https://doi.org/10.5194/acp10-7907-2010, 2010.

Merikanto, J., Spracklen, D. V., Mann, G. W., Pickering, S. J., and Carslaw, K. S.: Impact of nucleation on global CCN, Atmos. Chem. Phys., 9, 8601-8616, https://doi.org/10.5194/acp-9-86012009, 2009.

Mohr, C., Thornton, J. A., Heitto, A., Lopez-Hilfiker, F. D., Lutz, A., Riipinen, I., Hong, J., Donahue, N. M., Hallquist, M., Petäjä, T., Kulmala, M., and Yli-Juuti, T.: Molecular identification of organic vapors driving atmospheric nanoparticle growth, Nat. Commun., 10, 4442, https://doi.org/10.1038/s41467-019-124732, 2019.

Nie, W., Ding, A., Wang, T., Kerminen, V. M., George, C., Xue, L., Wang, W., Zhang, Q., Petäjä, T., Qi, X., Gao, X., Wang, X., Yang, X., Fu, C., and Kulmala, M.: Polluted dust promotes new particle formation and growth, Sci. Rep., 4, 6634, https://doi.org/10.1038/srep06634, 2014.

Nieminen, T., Lehtinen, K. E. J., and Kulmala, M.: Sub-10 nm particle growth by vapor condensation - effects of vapor molecule size and particle thermal speed, Atmos. Chem. Phys., 10, 9773 9779, https://doi.org/10.5194/acp-10-9773-2010, 2010.

Nieminen, T., Kerminen, V.-M., Petäjä, T., Aalto, P. P., Arshinov, M., Asmi, E., Baltensperger, U., Beddows, D. C. S., Beukes, J. P., Collins, D., Ding, A., Harrison, R. M., Henzing, B., Hooda, R., Hu, M., Hõrrak, U., Kivekäs, N., Komsaare, K., Krejci, R., Kristensson, A., Laakso, L., Laaksonen, A., Leaitch, W. R., Lihavainen, H., Mihalopoulos, N., Németh, Z., Nie, W., O’Dowd, C., Salma, I., Sellegri, K., Svenningsson, B., Swietlicki, E., Tunved, P., Ulevicius, V., Vakkari, V., Vana, M., Wiedensohler, A., Wu, Z., Virtanen, A., and Kulmala, M.: Global analysis of continental boundary layer new particle formation based on longterm measurements, Atmos. Chem. Phys., 18, 14737-14756, https://doi.org/10.5194/acp-18-14737-2018, 2018.

Pandolfi, M., Gonzalez-Castanedo, Y., Alastuey, A., de la Rosa, J. D., Mantilla, E., de la Campa, A. S., Querol, X., Pey, J., Amato, F., and Moreno, T.: Source apportionment of $\mathrm{PM}_{10}$ and $\mathrm{PM}_{2.5}$ at multiple sites in the strait of Gibraltar by PMF: Impact of shipping emissions, Environ. Sci. Pollut. Res., 18, 260-269, https://doi.org/10.1007/s11356-010-0373-4, 2011.

Patrón, D., Lyamani, H., Titos, G., Casquero-Vera, J. A., Cardell, C., Močnik, G., Alados-Arboledas, L., and Olmo, F. J.: Monumental heritage exposure to urban black carbon pollution, Atmos. Environ., 170, 22-32, https://doi.org/10.1016/j.atmosenv.2017.09.030, 2017.

Pérez, N., Pey, J., Cusack, M., Reche, C., Querol, X., Alastuey, A. and Viana, M.: Variability of particle number, black carbon, and $\mathrm{PM}_{10}, \mathrm{PM}_{2.5}$, and $\mathrm{PM}_{1}$ Levels and Speciation: Influence of road traffic emissions on urban air quality, Aerosol Sci. Tech., 44, 487-499, 2010.

Petäjä, T., Mauldin, III, R. L., Kosciuch, E., McGrath, J., Nieminen, T., Paasonen, P., Boy, M., Adamov, A., Kotiaho, T., and Kulmala, M.: Sulfuric acid and $\mathrm{OH}$ concentrations in a boreal forest site, Atmos. Chem. Phys., 9, 7435-7448, https://doi.org/10.5194/acp9-7435-2009, 2009.

Pey, J., Alastuey, A., Querol, X., and Rodríguez, S.: Monitoring of sources and atmospheric processes controlling air quality in an urban Mediterranean environment, Atmos. Environ., 44, 48794890, https://doi.org/10.1016/j.atmosenv.2010.08.034, 2010.

Pierce, J. R. and Adams, P. J.: Uncertainty in global CCN concentrations from uncertain aerosol nucleation and primary emission rates, Atmos. Chem. Phys., 9, 1339-1356, https://doi.org/10.5194/acp-9-1339-2009, 2009.

Pirjola, L., Kulmala, M., Wilck, M., Bischoff, A., Stratmann, F., and Otto, E.: Formation of sulphuric acid aerosols and cloud condensation nuclei: An expression for significant nucleation and model comparison, J. Aerosol Sci., 30, 1079-1094, https://doi.org/10.1016/S0021-8502(98)00776-9, 1999.

Querol, X., Alastuey, A., Rodriguez, S., Plana, F., Ruiz, C. R., Cots, N., Massagué, G. and Puig, O.: $\mathrm{PM}_{10}$ and $\mathrm{PM}_{2.5}$ source apportionment in the Barcelona Metropolitan area, Catalonia, Spain, Atmos. Environ., 35, 6407-6419, https://doi.org/10.1016/S13522310(01)00361-2, 2001.

Rönkkö, T., Kuuluvainen, H., Karjalainen, P., Keskinen, J., Hillamo, R., Niemi, J. V., Pirjola, L., Timonen, H. J., Saarikoski, S., Saukko, E., Järvinen, A., Silvennoinen, H., Rostedt, A., Olin, M., Yli-Ojanperä, J., Nousiainen, P., Kousa, A., and Dal Maso, M.: Traffic is a major source of atmospheric nanocluster aerosol, P. Natl. Acad. Sci. USA, 114, 7549-7554, https://doi.org/10.1073/pnas.1700830114, 2017.

Rose, C., Sellegri, K., Freney, E., Dupuy, R., Colomb, A., Pichon, J.-M., Ribeiro, M., Bourianne, T., Burnet, F., and Schwarzenboeck, A.: Airborne measurements of new particle formation in the free troposphere above the Mediterranean Sea during the HYMEX campaign, Atmos. Chem. Phys., 15, 10203-10218, https://doi.org/10.5194/acp-15-10203-2015, 2015.

Rose, C., Sellegri, K., Moreno, I., Velarde, F., Ramonet, M., Weinhold, K., Krejci, R., Andrade, M., Wiedensohler, A., Ginot, P., and Laj, P.: CCN production by new particle formation in the free troposphere, Atmos. Chem. Phys., 17, 1529-1541, https://doi.org/10.5194/acp-17-1529-2017, 2017.

Schobesberger, S., Junninen, H., Bianchi, F., Lönn, G., Ehn, M., Lehtipalo, K., Dommen, J., Ehrhart, S., Ortega, I. K., Franchin, A., Nieminen, T., Riccobono, F., Hutterli, M., Duplissy, J., Almeida, J., Amorim, A., Breitenlechner, M., Downard, A. J., Dunne, E. M., Flagan, R. C., Kajos, M., Keskinen, H., Kirkby, J., Kupc, A., Kürten, A., Kurtén, T., Laaksonen, A., Mathot, 
S., Onnela, A., Praplan, A. P., Rondo, L., Santos, F. D., Schallhart, S., Schnitzhofer, R., Sipilä, M., Tomé, A., Tsagkogeorgas, G., Vehkamäki, H., Wimmer, D., Baltensperger, U., Carslaw, K. S., Curtius, J., Hansel, A., Petäjä, T., Kulmala, M., Donahue, N. M., and Worsnop, D. R.: Molecular understanding of atmospheric particle formation from sulfuric acid and large oxidized organic molecules, P. Natl. Acad. Sci. USA, 110, 17223-17228, https://doi.org/10.1073/pnas.1306973110, 2013.

Sellegri, K., Rose, C., Marinoni, A., Lupi, A., Wiedensohler, A., Andrade, M., Bonasoni, P., and Laj, P.: New particle formation: A review of ground-based observations at mountain research stations, Atmosphere, 10, 493, https://doi.org/10.3390/atmos10090493, 2019.

Spracklen, D. V., Carslaw, K. S., Kulmala, M., Kerminen, V. M., Sihto, S. L., Riipinen, I., Merikanto, J., Mann, G. W., Chipperfield, M. P., Wiedensohler, A., Birmili, W., and Lihavainen, H.: Contribution of particle formation to global cloud condensation nuclei concentrations, Geophys. Res. Lett., 35, L06808, https://doi.org/10.1029/2007GL033038, 2008.

Spracklen, D. V., Carslaw, K. S., Merikanto, J., Mann, G. W., Reddington, C. L., Pickering, S., Ogren, J. A., Andrews, E., Baltensperger, U., Weingartner, E., Boy, M., Kulmala, M., Laakso, L., Lihavainen, H., Kivekäs, N., Komppula, M., Mihalopoulos, N., Kouvarakis, G., Jennings, S. G., O’Dowd, C., Birmili, W., Wiedensohler, A., Weller, R., Gras, J., Laj, P., Sellegri, K., Bonn, B., Krejci, R., Laaksonen, A., Hamed, A., Minikin, A., Harrison, R. M., Talbot, R., and Sun, J.: Explaining global surface aerosol number concentrations in terms of primary emissions and particle formation, Atmos. Chem. Phys., 10, 4775-4793, https://doi.org/10.5194/acp-10-4775-2010, 2010.

Tegen, I. and Schepanski, K.: The global distribution of mineral dust, IOP Conf. Ser. Earth Environ. Sci., 7, 012001, https://doi.org/10.1088/1755-1307/7/1/012001, 2009.

Titos, G., Foyo-Moreno, I., Lyamani, H., Querol, X., Alastuey, A., and Alados-Arboledas, L.: Optical properties and chemical composition of aerosol particles at an urban location: An estimation of the aerosol mass scattering and absorption efficiencies, J. Geophys. Res.-Atmos., 117, D04206, https://doi.org/10.1029/2011JD016671, 2012.

Titos, G., del Águila, A., Cazorla, A., Lyamani, H., CasqueroVera, J. A., Colombi, C., Cuccia, E., Gianelle, V., Močnik, G., Alastuey, A., Olmo, F. J., and Alados-Arboledas, L.: Spatial and temporal variability of carbonaceous aerosols: Assessing the impact of biomass burning in the urban environment, Sci. Total Environ., 578, 613-625, https://doi.org/10.1016/j.scitotenv.2016.11.007, 2017.

Tröstl, J., Chuang, W. K., Gordon, H., Heinritzi, M., Yan, C., Molteni, U., Ahlm, L., Frege, C., Bianchi, F., Wagner, R., Simon, M., Lehtipalo, K., Williamson, C., Craven, J. S., Duplissy, J., Adamov, A., Almeida, J., Bernhammer, A. K., Breitenlechner, M., Brilke, S., Dias, A., Ehrhart, S., Flagan, R. C., Franchin, A., Fuchs, C., Guida, R., Gysel, M., Hansel, A., Hoyle, C. R., Jokinen, T., Junninen, H., Kangasluoma, J., Keskinen, H., Kim, J., Krapf, M., Kürten, A., Laaksonen, A., Lawler, M., Leiminger, M., Mathot, S., Möhler, O., Nieminen, T., Onnela, A., Petäjä, T., Piel, F. M., Miettinen, P., Rissanen, M. P., Rondo, L., Sarnela, N., Schobesberger, S., Sengupta, K., Sipilä, M., Smith, J. N., Steiner, G., Tomè, A., Virtanen, A., Wagner, A. C., Weingartner, E., Wimmer, D., Winkler, P. M., Ye, P.,
Carslaw, K. S., Curtius, J., Dommen, J., Kirkby, J., Kulmala, M., Riipinen, I., Worsnop, D. R., Donahue, N. M., and Baltensperger, U.: The role of low-volatility organic compounds in initial particle growth in the atmosphere, Nature, 533, 527-531, https://doi.org/10.1038/nature18271, 2016.

Tuovinen, S., Kontkanen, J., Jiang, J., and Kulmala, M.: Investigating the effectiveness of condensation sink based on heterogeneous nucleation theory, J. Aerosol Sci., 149, 105613, https://doi.org/10.1016/j.jaerosci.2020.105613, 2020.

Valenzuela, A., Olmo, F. J., Lyamani, H., Antón, M., Titos, G., Cazorla, A., and Alados-Arboledas, L.: Aerosol scattering and absorption Angström exponents as indicators of dust and dust-free days over Granada (Spain), Atmos. Res., 154, 1-13, https://doi.org/10.1016/j.atmosres.2014.10.015, 2015.

Venzac, H., Sellegri, K., Laj, P., Villani, P., Bonasoni, P., Marinoni, A., Cristofanelli, P., Calzolari, F., Fuzzi, S., Decesari, S., Facchini, M. C., Vuillermoz, E., and Verza, G. Pietro: High frequency new particle formation in the Himalayas, P. Natl. Acad. Sci. USA, 105, 15666-15671, https://doi.org/10.1073/pnas.0801355105, 2008.

Venzac, H., Sellegri, K., Villani, P., Picard, D., and Laj, P.: Seasonal variation of aerosol size distributions in the free troposphere and residual layer at the puy de Dôme station, France, Atmos. Chem. Phys., 9, 1465-1478, https://doi.org/10.5194/acp-9-1465-2009, 2009.

Weingartner, E., Nyeki, S., and Baltensperger, U.: Seasonal and diurnal variation of aerosol size distributions $(10<\mathrm{D}<750 \mathrm{~nm})$ at a high-alpine site (Jungfraujoch $3580 \mathrm{~m}$ asl), J. Geophys. Res.-Atmos., 104, 26809-26820, https://doi.org/10.1029/1999JD900170, 1999.

Wiedensohler, A., Birmili, W., Nowak, A., Sonntag, A., Weinhold, K., Merkel, M., Wehner, B., Tuch, T., Pfeifer, S., Fiebig, M., Fjäraa, A. M., Asmi, E., Sellegri, K., Depuy, R., Venzac, H., Villani, P., Laj, P., Aalto, P., Ogren, J. A., Swietlicki, E., Williams, P., Roldin, P., Quincey, P., Hüglin, C., Fierz-Schmidhauser, R., Gysel, M., Weingartner, E., Riccobono, F., Santos, S., Grüning, C., Faloon, K., Beddows, D., Harrison, R., Monahan, C., Jennings, S. G., O’Dowd, C. D., Marinoni, A., Horn, H.-G., Keck, L., Jiang, J., Scheckman, J., McMurry, P. H., Deng, Z., Zhao, C. S., Moerman, M., Henzing, B., de Leeuw, G., Löschau, G., and Bastian, S.: Mobility particle size spectrometers: harmonization of technical standards and data structure to facilitate high quality long-term observations of atmospheric particle number size distributions, Atmos. Meas. Tech., 5, 657-685, https://doi.org/10.5194/amt-5-657-2012, 2012.

Wiedensohler, A., Wiesner, A., Weinhold, K., Birmili, W., Hermann, M., Merkel, M., Müller, T., Pfeifer, S., Schmidt, A., Tuch, T., Velarde, F., Quincey, P., Seeger, S., and Nowak, A.: Mobility particle size spectrometers: Calibration procedures and measurement uncertainties, Aerosol Sci. Tech., 52, 146-164, https://doi.org/10.1080/02786826.2017.1387229, 2018.

Yao, L., Garmash, O., Bianchi, F., Zheng, J., Yan, C., Kontkanen, J., Junninen, H., Mazon, S. B., Ehn, M., Paasonen, P., Sipilä, M., Wang, M., Wang, X., Xiao, S., Chen, H., Lu, Y., Zhang, B., Wang, D., Fu, Q., Geng, F., Li, L., Wang, H., Qiao, L., Yang, X., Chen, J., Kerminen, V. M., Petäjä, T., Worsnop, D. R., Kulmala, M., and Wang, L.: Atmospheric new particle formation from sulfuric acid and amines in a Chinese megacity, Science, 361, 278281, https://doi.org/10.1126/science.aao4839, 2018. 
Yli-Juuti, T., Nieminen, T., Hirsikko, A., Aalto, P. P., Asmi, E., Hõrrak, U., Manninen, H. E., Patokoski, J., Dal Maso, M., Petäjä, T., Rinne, J., Kulmala, M., and Riipinen, I.: Growth rates of nucleation mode particles in Hyytiälä during 2003-2009: variation with particle size, season, data analysis method and ambient conditions, Atmos. Chem. Phys., 11, 12865-12886, https://doi.org/10.5194/acp-11-12865-2011, 2011.
Zhang, R., Khalizov, A., Wang, L., Hu, M., and Xu, W.: Nucleation and growth of nanoparticles in the atmosphere, Chem. Rev., 112, 1957-2011, https://doi.org/10.1021/cr2001756, 2012. 